\title{
Types of Fluid Alteration and Developing Mechanism of Deep Marine Carbonate Reservoirs
}

\author{
Dongya Zhu $\mathbb{D}^{1,2}$ Quanyou Liu, ${ }^{1,2}$ Juntao Zhang $\mathbb{D}^{1,2}$ Qian Ding $\mathbb{D}^{1,2}$ Zhiliang He ${ }^{1}{ }^{1,2}$ \\ and Xuefeng Zhang ${ }^{3}{ }^{3}$ \\ ${ }^{1}$ State Key Laboratory of Shale Oil and Gas Enrichment Mechanisms and Effective Development, SINOPEC, No. 31 Xueyuan Road, \\ Beijing 100083, China \\ ${ }^{2}$ Petroleum Exploration and Production Research Institute, Laboratory of Structural and Sedimentary Reservoir Geology, SINOPEC, \\ No. 31 Xueyuan Road, Beijing 100083, China \\ ${ }^{3}$ School of Earth and Space Sciences, Peking University, Beijing 100871, China
}

Correspondence should be addressed to Dongya Zhu; zhudy.syky@sinopec.com

Received 22 February 2019; Revised 9 April 2019; Accepted 28 May 2019; Published 24 June 2019

Academic Editor: Julien Bourdet

Copyright (c) 2019 Dongya Zhu et al. This is an open access article distributed under the Creative Commons Attribution License, which permits unrestricted use, distribution, and reproduction in any medium, provided the original work is properly cited.

\begin{abstract}
Accurate recognition of the types of alteration fluid and the development mechanisms are important concerns in studying deep marine carbonate reservoirs. Major fluid types, such as seawater, meteoric water, deep burial formation water, hydrothermal fluid, and thermochemical sulfate reduction- (TSR-) derived fluid, were identified based on carbon, oxygen, and strontium isotope compositions of many samples from the Tarim, Sichuan, and Ordos basins in China. Compared with normal marine limestones, seawater calcite cement has similar isotopic compositions. Calcite cement precipitated from meteoric water has extremely light oxygen isotope compositions, and its $\delta^{18} \mathrm{O}_{\mathrm{V}-\mathrm{PDB}}$ reaches $-18.8 \%$. Due to the fractionation of oxygen isotopes at high temperatures $\left(101.2 \sim 145.6^{\circ} \mathrm{C}\right)$, calcite precipitated from deep burial formation water and deep hydrothermal fluid has moderately light oxygen isotope compositions. The TSR process consumes organic matter to produce $\mathrm{CO}_{2} / \mathrm{CO}_{3}{ }^{2-}$, and the calcite from TSR-derived fluid has very light carbon isotopes $\left(\delta^{18} \mathrm{O}_{\mathrm{V}-\mathrm{PDB}},-18.9 \%\right)$ due to the incorporation of organic $\mathrm{CO}_{2} / \mathrm{CO}_{3}{ }^{2-}$. Formation water and TSR-derived fluid generally originate and are confined within the carbonates and are consequently termed endogenous fluids. The ${ }^{87} \mathrm{Sr} /{ }^{86} \mathrm{Sr}$ ratios of calcite cements from endogenous fluids are basically the same as those of surrounding carbonates. Meteoric water and hydrothermal fluid originate outside the carbonate strata and are exogenous fluids. The ${ }^{87} \mathrm{Sr} /{ }^{86} \mathrm{Sr}$ ratios of calcite cements from exogenous fluids are higher than those of surrounding carbonates, up to 0.710558 . For karst carbonate reservoirs developed in tectonic uplift-meteoric water environments, the reservoir spaces of karst caves and fractures occur principally under and near unconformity surfaces and megacrystalline calcite cements occur below the karst zone. In deep fault-hydrothermal fluid environments, high-quality carbonate reservoirs develop downward into ultradeep strata. In deep burial-TSR-derived fluid environments, dissolution porosity can be well preserved for a long geological time due to high $\mathrm{CO}_{2}$ and $\mathrm{H}_{2} \mathrm{~S}$ concentrations.
\end{abstract}

\section{Introduction}

A large number of exploration examples worldwide have revealed abundant oil and gas resources in deep/ultradeep layers, mainly due to the occurrence of high-quality carbonate reservoirs. The deepest gas-producing layer in the Mills Ranch gas field in the Anadarko Basin, USA, is the Hunton Formation dolomite reservoir in the Upper Ordovician to
Lower Devonian, with burial depths exceeding $26000 \mathrm{ft}$ (7924 m) [1, 2]. A few drilling wells, e.g., the TS1 well in the Tarim Basin and the MS1 well in the Sichuan Basin, have discovered hydrocarbons in deep/ultradeep high-quality carbonate reservoirs with depth $>8000 \mathrm{~m}$, and several largescale deep/ultradeep Paleozoic carbonate oil and gas fields have been found in the Tarim, Sichuan, and Ordos basins in China (Figure 1). 

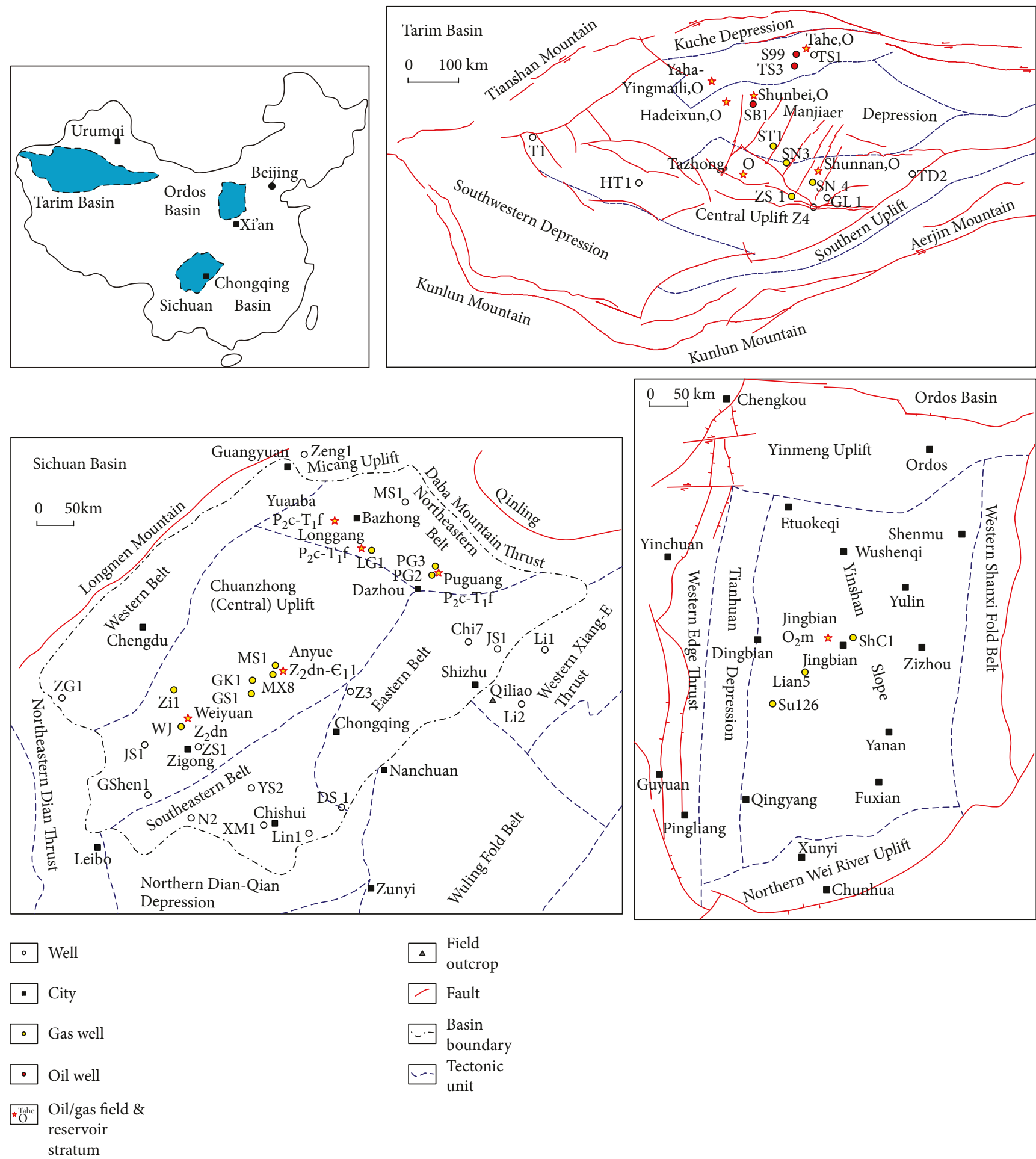

FIGURE 1: Distribution of major carbonate reservoirs and drilling wells in the Tarim, Sichuan, and Ordos basins in China.

The formation of deep high-quality carbonate reservoirs is closely related to various types of fluid alteration after sedimentation, such as meteoric water karstification $[3,4]$, mesogenetic dissolution by acidic fluid (organic acid, $\mathrm{CO}_{2}$, etc.) generated from the maturation of organic matter [5-7], hydrothermal dissolution and hydrothermal dolomitization $[8,9]$, and alteration of $\mathrm{H}_{2} \mathrm{~S}$ and $\mathrm{CO}_{2}$ related to ther- mochemical sulfate reduction (TSR) [10-13]. Deep carbonates in the Tarim, Sichuan, and Ordos basins have all undergone complex tectonic evolution, subsidence and burial, uplift, and denudation processes [14] and thus have experienced complex dissolution and alteration by various types of fluid [15]. How to accurately identify the types of fluid alteration in deep carbonate reservoirs is of great 
significance in searching for high-quality deep carbonate reservoirs. The occurrence and development of fluid alterations are generally related to specific tectonic backgrounds; thus, a better understanding of the tectonic-fluid environments is necessary. In addition, the development mechanisms of deep carbonate reservoirs in different tectonic-fluid environments should be studied in detail.

Minor elements, such as Fe and Mn, were used to identify hydrothermal fluid alteration $[16,17]$, and rare earth elements were used to identify alterations related to meteoric water and hydrothermal fluids [18]. However, differentiating complex fluid alteration processes in deep carbonate reservoirs using element compositions is very difficult. Sampling, analyzing carbon, oxygen, and strontium isotope compositions of carbonates, and determining the homogenization temperatures of fluid inclusions are very easy, and a combination of these parameters can effectively discriminate each type of fluid alteration.

In this study, based on a large number of samples from the lower Paleozoic deep/ultradeep carbonate reservoirs in the Tarim, Sichuan, and Ordos basins in China, we (1) statistically analyzed strontium, carbon, and oxygen isotopes and homogenization temperatures of fluid inclusions to identify the fluid types; (2) determined the tectonic background and tectonic-fluid environments for the development of different fluid alterations; and (3) investigated the characteristics and development mechanisms of high-quality reservoirs in different tectonic-fluid environments.

\section{Geological Background}

Deep oil and gas resources are generally those in reservoirs with depths between $4500 \mathrm{~m}$ and $6000 \mathrm{~m}$ [19]. If the depth is greater than $6000 \mathrm{~m}$, the reservoir is called ultradeep [19]. Deep to ultradeep reservoirs are currently the key targets of oil and gas exploration. There are 968 production wells with drilling depths exceeding $6000 \mathrm{~m}$ in the United States [20], 52 of which have drilling depths exceeding $7500 \mathrm{~m} \mathrm{[21].} \mathrm{The} \mathrm{oil}$ and gas reservoir discovered by Chevron Company in the Paleogene Jack and St. Malo area in the Gulf of Mexico is the largest ultradeep reservoir ever discovered. The Jack reservoir has a burial depth of $8839 \mathrm{~m}$ and has oil and gas geological reserves of $6821 \times 10^{4} \mathrm{t}$ oil equivalent [14]. The deepest gas-producing reservoir in the Mills Ranch gas field in the Anadarko Basin is the Hunton Formation dolomite reservoir from the Upper Ordovician to Lower Devonian, and its burial depth exceeds $7924 \mathrm{~m}(26000 \mathrm{ft})$ [1].

Large-scale deep marine carbonate reservoirs in China are mainly distributed in the Tarim Basin, Sichuan Basin, and Ordos Basin (Figure 1). The main characteristics of the deep carbonate reservoirs are that they are found in old and deeply buried strata, experienced multistage tectonic transformations, and have been seriously destroyed and deformed [22]. Therefore, multiple stages and types of fluid alterations are important for the development of high-quality deep carbonate reservoirs [14]. The Tarim, Sichuan, and Ordos basins have similarly undergone early seawater alteration, meteoric water alteration during tectonic uplift, formation water alteration and TSR-related fluid alteration during deep burial, and fault-hydrothermal alteration [23].

The major deep marine carbonate oil and gas fields in the Sichuan Basin include the Anyue gas field in shoal dolomite reservoirs of the Sinian Dengying Formation and lower Cambrian Longwangmiao Formation and the Puguang, Yuanba, and Longgang gas fields in reef and shoal dolomite reservoirs of the upper Permian Changxing Formation and Lower Triassic Feixianguan Formation. In the Tarim Basin are the Tahe, Tazhong, and Hadeixun oil fields in the Ordovician karst limestone reservoirs and the Shunnan and Shunbei oil fields in the Ordovician faulted and hydrothermally altered carbonate reservoirs. In the Ordos Basin, the Jingbian gas field is the major gas field, which is predominantly in karst dolomite reservoirs of the Ordovician Majiagou Formation.

Most of these large oil and gas fields, such as the Anyue, Puguang, and Yuanba gas fields in the Sichuan Basin and the Tahe and Hadeixun oil fields in the Tarim Basin, are buried at current depths of more than $5000 \mathrm{~m}$. For example, in the Yuanba gas field, the burial depth of the upper Permian Changxing Formation dolomite reservoir is between $6200 \mathrm{~m}$ and $7300 \mathrm{~m}$. Many wells in the Shunnan and Shunbei oil and gas fields have revealed industrial oil and gas reservoirs below $7000 \mathrm{~m}$ [24]. Among them, the SB1-1H well obtained high-yielding oil and gas flows (oil pressure of 42.3 $\mathrm{MPa}$, oil production of $129 \mathrm{t} / \mathrm{day}$, and natural gas production of $6.49 \times 10^{4} \mathrm{~m}^{3} /$ day) at $7658-7874 \mathrm{~m}$ in the Yijianfang and Yingshan formations.

In 2006, the TS1 well was drilled in the southeastern Akekule uplift in the Tarim Basin. The well depth was $8408 \mathrm{~m}$, the temperature was higher than $170^{\circ} \mathrm{C}$, and the pressure was greater than $80 \mathrm{MPa}$. The high-quality dolomite reservoir was drilled at depths greater than $8000 \mathrm{~m}$, where the porosity was as high as $9.1 \%$. Liquid hydrocarbons were present in the ultradeep dolomite reservoir [25]. The ZS1 well in the Tazhong uplift generated a daily gas production of $21.67 \times 10^{4} \mathrm{~m}^{3} /$ day at $6861-6944 \mathrm{~m}$ in a Cambrian dolomite reservoir. The MS1 well, located in the northern Sichuan Basin, was drilled in 2016 to a depth of $8418 \mathrm{~m}$ and showed an excellent gas-bearing dolomite reservoir in the Sinian Dengying Formation at 8044-8418 m.

\section{Samples and Methods}

Cements of carbonate minerals (calcite, dolomite, etc.) often fill dissolution pores or fractures (Figures 2 and 3) after deep carbonate reservoirs are altered by later diagenetic fluids. The carbon, oxygen, and strontium isotopes in the calcite and dolomite cements were measured to trace the related fluid alteration types.

Calcite and dolomite samples were collected from the lower Paleozoic deep carbonate reservoirs in the Tarim, Sichuan, and Ordos basins, mostly from drill cores and partly from field outcrops. The total number of samples was 311 . Among them, 122, 138, and 51 were from the Tarim, Sichuan, and Ordos basins, respectively.

The large calcite and dolomite samples in vugs or fractures (millimeter-centimeter in size) were mechanically 


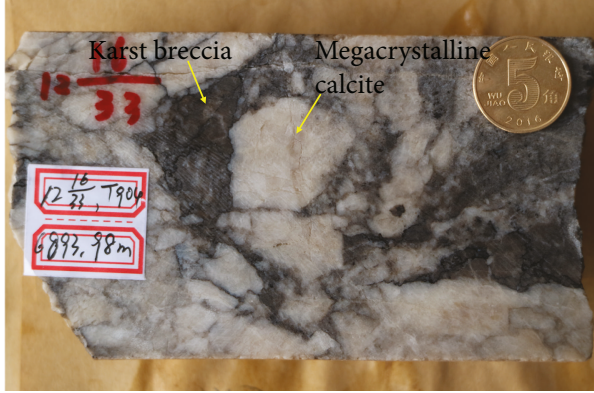

(a)

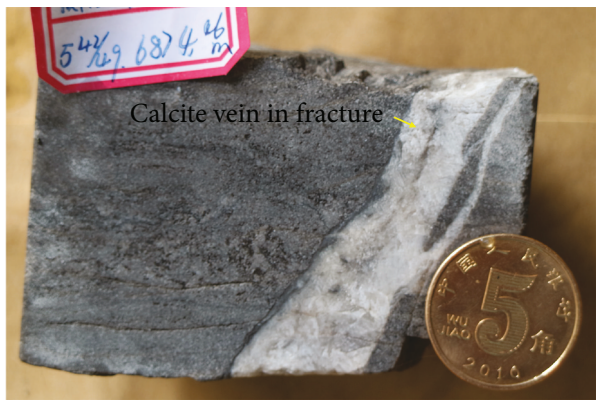

(c)

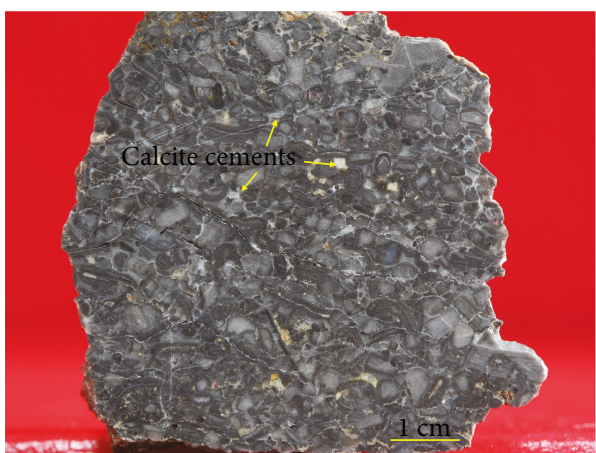

(e)

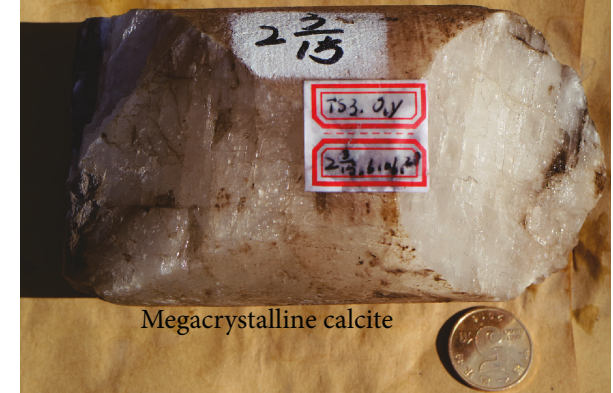

(b)

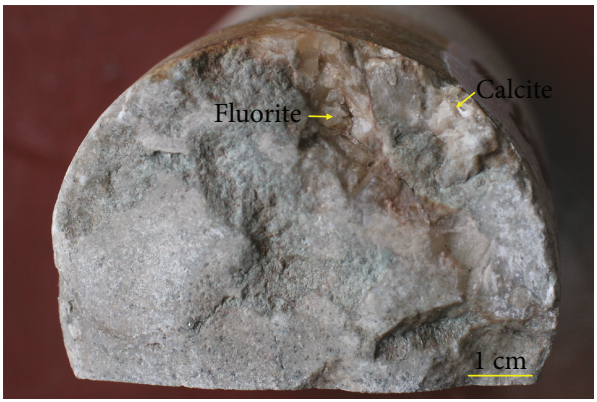

(d)

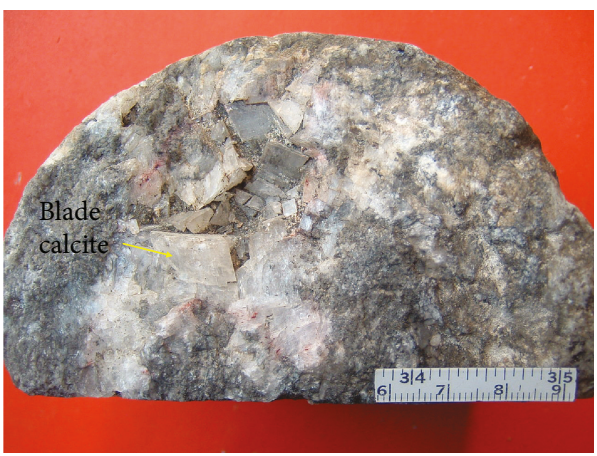

(f)

Figure 2: Petrological and mineralogical characteristics of carbonate rocks with fluid alteration. (a) Megacrystalline calcite filled among karst breccia in karst cave (from the T904 well, $\mathrm{O}_{2} \mathrm{yj}$, at $6893.98 \mathrm{~m}$ ) in the Tahe oil field, Tarim Basin. (b) Megacrystalline calcite filling karst cave (from the TS3 well, $\mathrm{O}_{1} \mathrm{y}$, at $6106.28 \mathrm{~m}$ ) in the Tahe oil field. (c) Calcite vein filling limestone fracture (from the SN2 well, $\mathrm{O}_{1} \mathrm{y}$, at $6874.46 \mathrm{~m}$ ) in the Shunnan oil field, Tarim Basin. (d) Calcite and fluorite vein filling limestone fracture (from the S110 well, $\mathrm{O}_{3} \mathrm{~s}$, at $6086.78 \mathrm{~m}$ ) in the Tahe oil field. (e) Calcite filled in bioclastic limestone $\left(\mathrm{O}_{2} \mathrm{~b}\right)$ at the Qiliao outcrop in Shizhu, Sichuan Basin. (f) Calcite filling karst cave in gray finemedium crystalline dolomite ( $\mathrm{T}_{1} \mathrm{f}$, from the PG2 well) in the Puguang gas field, Sichuan Basin.

crushed into small particles. The particles were screened through 40-60 meshes; then, pure mineral particles were hand-picked under a binocular microscope. For tiny calcite and dolomite samples (micrometer in size), slices with thicknesses of approximately $0.3-0.5 \mathrm{~mm}$ were ground. Pure mineral samples were taken using a microdriller on the slices.

The selected pure samples were further ground into powders of less than 200 mesh for analysis of carbon, oxygen, and strontium isotopes. Isotope analysis of carbon and oxygen was performed using the $100 \%$ phosphoric acid method on a MAT 252 mass spectrometer. Strontium isotope determination was carried out on a Finnigan MAT Triton TI mass spectrometer. The measured ${ }^{87} \mathrm{Sr} /{ }^{86} \mathrm{Sr}$ values were calibrated according to the mass fractionation standard of ${ }^{87} \mathrm{Sr} /{ }^{86} \mathrm{Sr}=0.1194$. The average $\mathrm{Sr}$ isotope ratio of the NBS987 standard sample was $0.710273 \pm 0.000012$.
The measurement of homogenization temperatures for fluid inclusions in minerals was carried out on a LinkamTH600 heating-cooling stage mounted in a Leica DM4500 microscope. Primary two-phase (gas-liquid) fluid inclusions larger than $6 \mu \mathrm{m}$ in authigenic minerals were chosen for measurement. After temperature adjustment, the measurement started at a temperature increase rate of $15^{\circ} \mathrm{C} / \mathrm{min}$, and the rate was decreased to $1^{\circ} \mathrm{C} / \mathrm{min}$ when the fluid inclusion was close to homogenization. The precision of temperature measurements was $\pm 1^{\circ} \mathrm{C}$.

\section{Results}

4.1. Petrographic Characteristics. According to drill core, field outcrop, and thin section observations, several types of calcite cement could be found in the pores, caves, and 


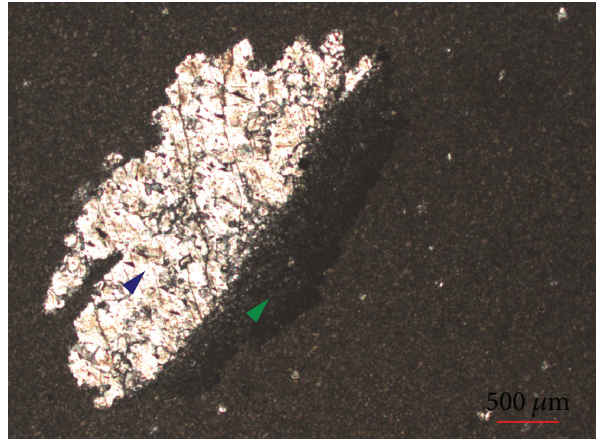

(a)

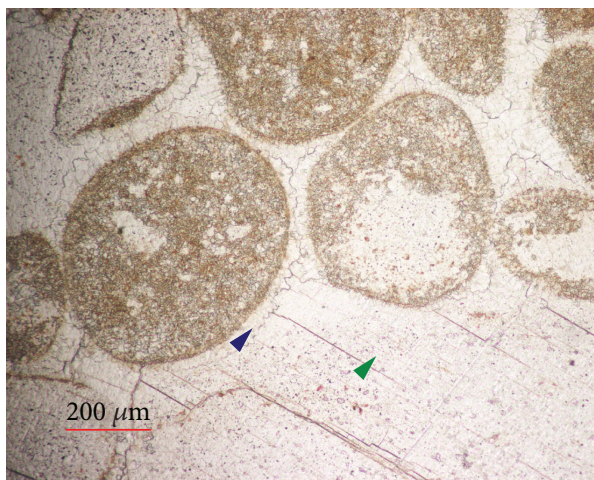

(c)

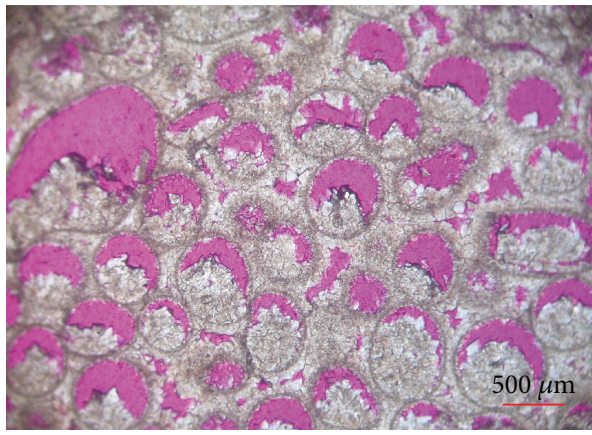

(e)

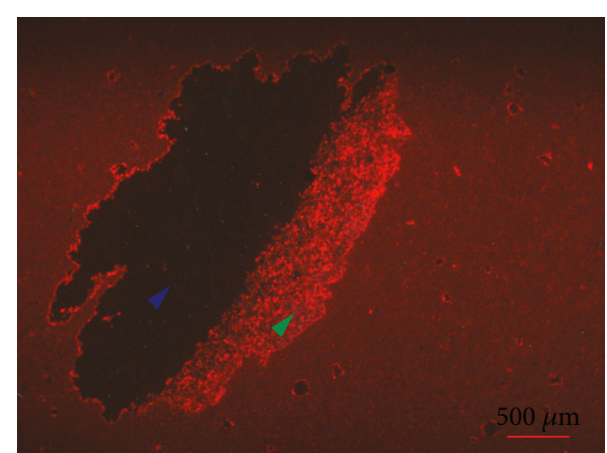

(b)

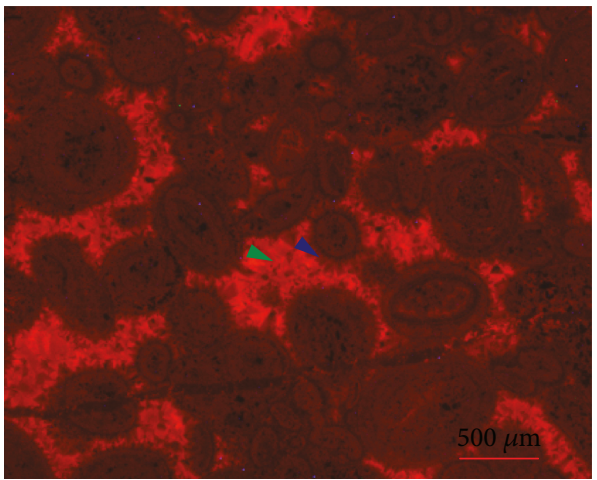

(d)

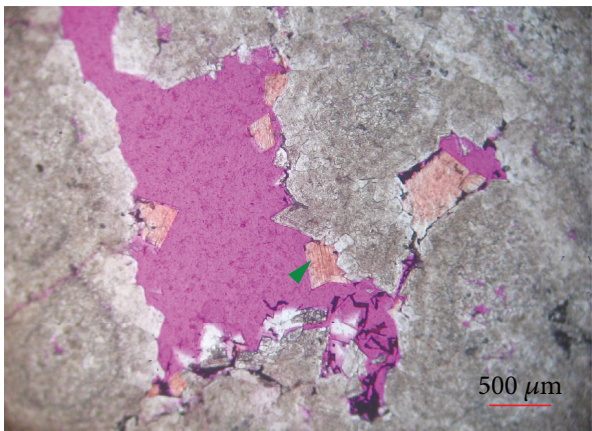

(f)

FIgURE 3: Microscopic characteristics of fluid dissolution in carbonate rocks. (a) Granular calcite (blue arrow) filled in casting cave after gypsum dissolution in fine crystalline dolomite. Karst residual debris (green arrow) occurs at the bottom of the cave $\left(\mathrm{O}_{2} \mathrm{~m}\right.$, polarized light, 25x, from well Lian 5, Ordos Basin). (b) Cathodoluminescence features of picture (a). Calcite filled in casting cave has no cathodoluminescence (blue arrow). Karst residual debris (green arrow) has dotted red cathodoluminescence. (c) Annular radial calcite (blue arrow) formed in early-stage seawater and granular calcite formed in deep burial formation water (green arrow) filling intergranular pores in granular limestone $\left(\mathrm{O}_{2} \mathrm{yj}, 100 \mathrm{x}\right.$, from well T708 of the Tahe oil field, Tarim Basin). (d) Annular radial calcite (blue arrow) formed in early seawater and granular calcite (green arrow) formed in the deep burial stage filling intergranular pore in oolitic limestone. They emit weak and bright red cathodoluminescence under cathode irradiation, respectively $\left(\mathrm{O}_{2} \mathrm{~b}, 25 \mathrm{x}\right.$, from the Qiliao outcrop in Shizhu, Sichuan Basin). (e) Oolitic dolomite rich in intragranular dissolution pores $\left(\mathrm{T}_{1} \mathrm{f}\right.$, at $5166 \mathrm{~m}, 40 \mathrm{x}$, from well PG2, Puguang gas field, Sichuan Basin). (f) Bladed calcite (green arrow), which is related to TSR, filling dissolution vug in medium-coarse crystalline dolomite ( $\mathrm{T}_{1} \mathrm{f}, 40 \mathrm{x}$, from well PG2, Puguang gas field, Sichuan Basin).

fractures in the deep carbonate strata. In the deep Ordovician carbonate reservoirs in the Tarim Basin, megacrystalline calcite was observed filling in karst caves (Figures 2(a) and 2(b)) in the T904 and TS3 wells. Annular radial calcite surrounding grains and coarse crystalline equiaxial granular calcite were found in the intergranular pores in the T708 well (Figure 3(c)). Under cathodic rays, the radial calcite and equiaxial granular calcite emitted weak dark red and light red cathodoluminescence, respectively (Figure 3(d)). A fracture was filled with a calcite vein in the SN2 well (Figure 2(c)). In the deep Ordovician carbonate reservoirs in the Ordos Basin, erosive residue was found to accumulate at the bottom of a dissolution vug in the Lian 5 well to form a bottom-identifying structure and the vug was filled with granular calcite, which did not emit cathodoluminescence under cathode ray irradiation (Figures 3(a) and 3(b)). In 
the Triassic Feixianguan Formation and Ordovician carbonate reservoirs in the Sichuan Basin, vugs and pores were filled with coarse bladed or granular crystalline calcite (Figures 2(e) and $3(\mathrm{f})$ ).

4.2. Isotope Compositions. According to the tectonic evolution process, petrological and mineralogical characteristics, and compositions of carbon, oxygen, and strontium isotopes, the calcite samples were classified into six categories, each representing one type of fluid alteration, including seawater alteration, dolomitization, deep burial formation water alteration, meteoric alteration, hydrothermal alteration, and TSR-related fluid alteration. Using a normal marine limestone as the comparison standard, each type of fluid alteration has different characteristic isotope compositions (Table 1).

The $\delta^{13} \mathrm{C}, \delta^{18} \mathrm{O}$, and ${ }^{87} \mathrm{Sr} /{ }^{86} \mathrm{Sr}$ of the Ordovician marine limestones in the Tarim Basin and Ordos Basin are between $-3.6 \%$ and $+2 \%$, $-9.7 \%$ and $-3.9 \%$ o, and 0.708150 and 0.709104 , respectively (Table 1 ). Those of the Early Triassic marine limestone in the Sichuan Basin are between $-1.2 \%$ o and $+2.2 \%$, $-8.4 \%$ ond $-5.2 \%$, and 0.70251 and 0.70774 , respectively (Table 1 ).

Compared with the normal marine limestone, the minerals (dolomite/calcite) of different origins have remarkably different carbon, oxygen, or strontium isotope compositions (Table 1). The carbon and oxygen isotope compositions of the Ordovician and Lower Triassic Feixianguan Formation cryptocrystalline and fine crystalline dolomite are slightly heavier (Figures 4 and 5), while the ${ }^{87} \mathrm{Sr} /{ }^{86} \mathrm{Sr}$ ratios are similar (Figure 6). The meteoric calcite has extremely lighter oxygen isotopes (Figures 4 and 5), with $\delta^{18} \mathrm{O}$ varying from $-18.8 \%$ to $-11.4 \%$, and significantly higher ${ }^{87} \mathrm{Sr} /{ }^{86} \mathrm{Sr}$ ratios varying from 0.709190 to 0.710558 (Figure 6). The hydrothermal calcite is significantly lighter in oxygen isotope compositions (Figures 4 and 5) with $\delta^{18} \mathrm{O}$ from -14.6\%o to $-7.1 \%$, and its strontium isotope ratios are higher (Figure 6), from 0.709049 to 0.709891 . The TSR calcite has much lighter carbon isotope compositions (Figure 4), with $\delta^{13} \mathrm{C}$ varying from $-18.9 \%$ o to $-3.5 \%$, but its ${ }^{87} \mathrm{Sr} /{ }^{86} \mathrm{Sr}$ ratios are within the range of marine limestone (Figure 6).

\section{Discussion}

5.1. Identification of Types of Fluid Alteration. The compositions of carbon, oxygen, and strontium isotopes in normal marine limestones may vary with the age of sedimentation; however, the influence of fluid dissolution and alteration on carbonates after sedimentation might be far greater than that of age. Globally, in the Ordovician and Early Triassic marine limestones, the $\delta^{13} \mathrm{C}, \delta^{18} \mathrm{O}$, and ${ }^{87} \mathrm{Sr} /{ }^{86} \mathrm{Sr}$ values vary from $-3 \%$ o to $+6 \%$, $-10 \%$ to $-3 \%$, and 0.7078 to 0.7095 and from $-3 \%$ o to $+4 \%$, $-5 \%$ o to $-2 \%$, and 0.7069 to 0.7083 , respectively [26]. The samples of Ordovician limestone in the Tarim, Ordos, and Sichuan basins and samples of the Triassic Feixianguan Formation limestone in the Sichuan Basin are completely consistent with the marine limestones in the same periods.
5.1.1. Dolomitization. After deposition in seawater, the earliest alteration of limestone was contemporaneous dolomitization. Previous studies have confirmed that various types of dolomitization mechanisms may operate, such as Sabha dolomitization, percolation-reflux dolomitization, mixed water dolomitization [27-29], burial dolomitization [30], hydrothermal dolomitization [31], and microbial dolomitization [32]. However, over geological history, large-scale dolomitization has generally occurred in restricted platform facies in evaporative hypersaline seawater environments at the contemporaneous stage, mainly according to the Sabha and seepage reflux models [27-29]. The majority of the Middle Ordovician dolomites in the northern Ordos Basin formed in evaporated refluxing seawater [33]. The matrix dolomites of the upper Cambrian-Lower Ordovician in the Tahe oil field, northern Tarim Basin, precipitated from seawater or seawater-related connate water [34]. In the Sichuan Basin, the Lower Ordovician dolomites formed from hypersaline seawater by the refluxing model [35].

Because of the existence of reefs or shoal barriers, the flow of seawater in the carbonate platform area could be limited, leading to the formation of hypersaline seawater due to continuous evaporation. As the concentration of $\mathrm{CaSO}_{4}$ in the evaporated seawater gradually exceeded the saturation point of gypsum, gypsum precipitated. This process reduced $\mathrm{Ca}^{2+}$ in seawater, leading to an increase in the seawater $\mathrm{Mg} / \mathrm{Ca}$ ratio. In normal seawater, the $\mathrm{Ma} / \mathrm{Ca}$ ratio is generally $5: 1$. When the ratio reaches $10: 1$, dolomite begins to precipitate [36].

With the increase in evaporation and concentration of seawater, the composition of the oxygen isotopes in the seawater gradually becomes heavier, but the ${ }^{87} \mathrm{Sr} /{ }^{86} \mathrm{Sr}$ ratio remains unchanged. The solubility of $\mathrm{CO}_{2}$ in seawater decreases with increasing salinity [37], so that some $\mathrm{CO}_{2}$ bubbles out from seawater. According to the principle of isotope fractionation, ${ }^{12} \mathrm{C}$ preferentially enters the gaseous $\mathrm{CO}_{2}$, while ${ }^{13} \mathrm{C}$ remains in the seawater [38]. As a result, the $\delta^{13} \mathrm{C}_{\mathrm{V}-\mathrm{PDB}}$ value of $\mathrm{CO}_{2}$ or $\mathrm{CO}_{3}{ }^{2-}$ in seawater gradually increases with an increasing evaporation level. Therefore, dolomite precipitated from seawater has relatively heavy carbon and oxygen isotope compositions.

The carbon and oxygen isotopes of the cryptocrystalline and fine crystalline dolomites in the Ordovician rocks in the Tarim Basin and Sichuan Basin and in the Lower Triassic Feixianguan Formation in the Sichuan Basin are heavier than those of the limestones of the same periods (Figure 4). The ${ }^{87} \mathrm{Sr} /{ }^{86} \mathrm{Sr}$ ratios are similar to those of limestones (Figure 6). The carbon, oxygen, and strontium isotope features indicate that the dolomites formed in a marine evaporative environment [35].

5.1.2. Seawater Cementation. Reef, bioclastic, or oolitic limestones with large numbers of primary pores could be cemented in seawater after sedimentation and before shallow burial. The seawater cement mineral was usually aragonite, showing radial needle crystals around carbonate particles. The radial aragonite gradually transformed into calcite, producing fibrous calcite cementation surrounding the edges of carbonate particles [39], and the fibrous calcite emitted 


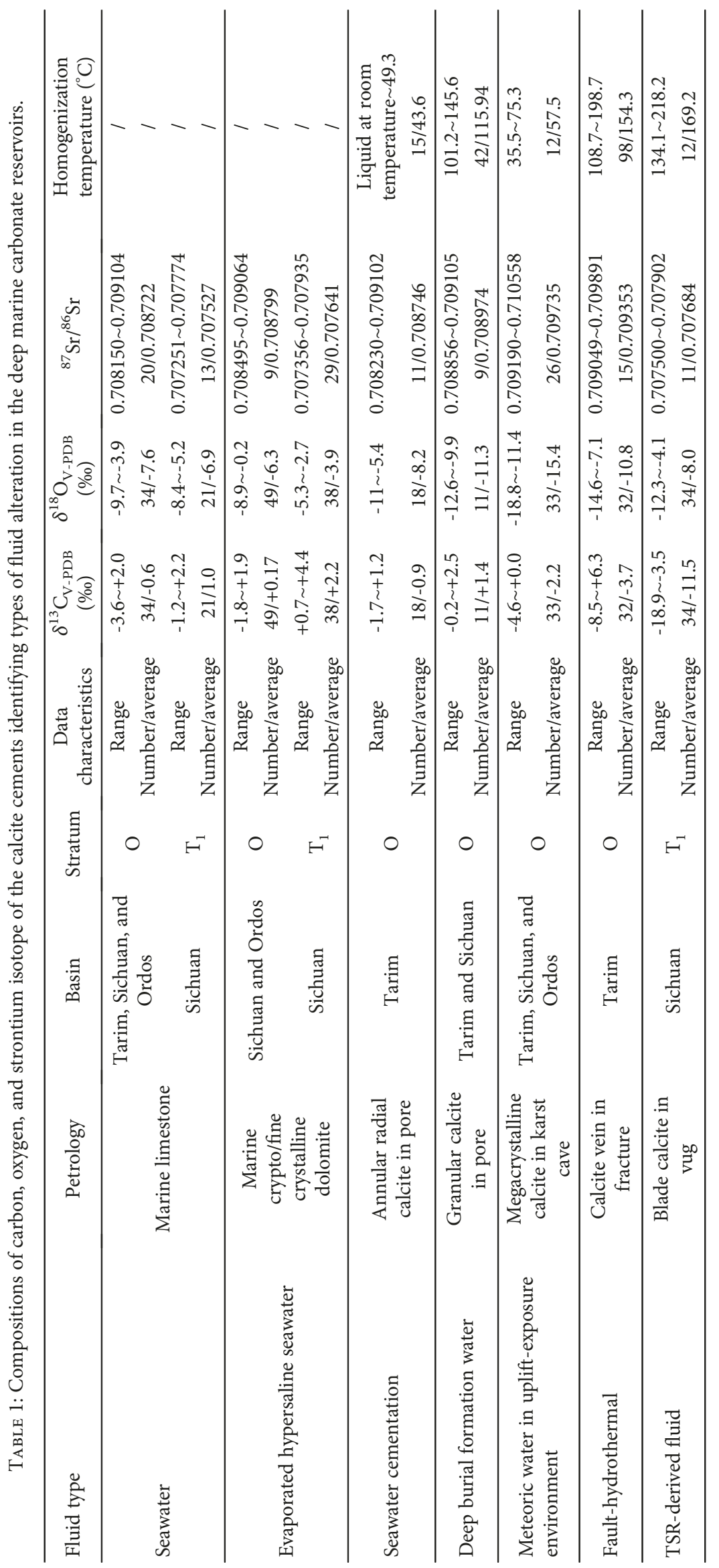




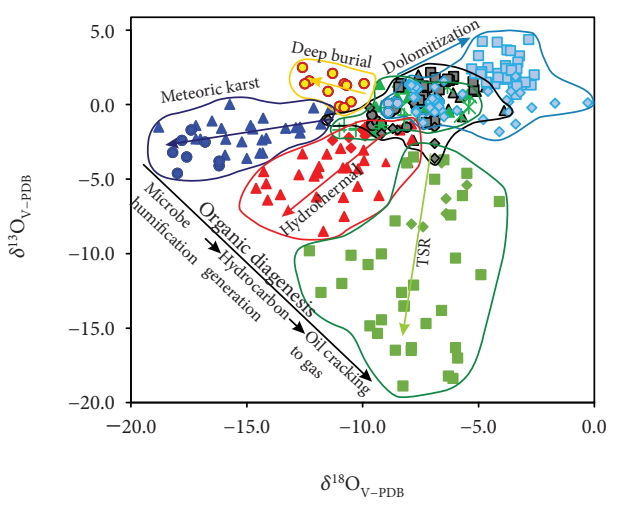

$\Delta$ Limestone $(\mathrm{O})$ in Tarim Basin

* Seawater calcite $(\mathrm{O})$ in Tarim Basin

- Shallow burial formation water calcite $(\mathrm{O})$ in Tarim Basin

Meteoric megacrystalline calcite $(\mathrm{O})$ in Tarim Basin

- Hydrothermal calcite $(\mathrm{O})$ in Tarim Basin

- Limestone $(\mathrm{O})$ in Sichuan Basin

+ Seawater calcite $(\mathrm{O})$ in Sichuan Basin

Deep burial formation water calcite $(\mathrm{O})$ in Sichuan Basin

- Meteoric megacrystalline calcite $(\mathrm{O})$ in Sichuan Basin

- Crypto/fine crystalline dolomite $\left(\mathrm{O}_{1}\right)$ in Sichuan Basin

- Limestone $\left(T_{1} f\right)$ in Sichuan Basin

- Crypto/fine crystalline dolomite $\left(T_{1}\right)$ in Sichuan Basin

- TSR calcite $(\mathrm{T}, \mathrm{f})$ in Sichuan Basin

- Limestone $(\mathrm{O})$ in Ordovician Basin

- Crypto/fine crystalline dolomite(O) in Ordovician Basin

- Hydrothermal dolomite $(\mathrm{O})$ in Ordovician Basin

- TSR calcite $(\mathrm{O})$ in Ordovician Basin

Figure 4: Carbon and oxygen isotope compositions to identify different fluid alterations in the deep marine carbonate reservoirs.

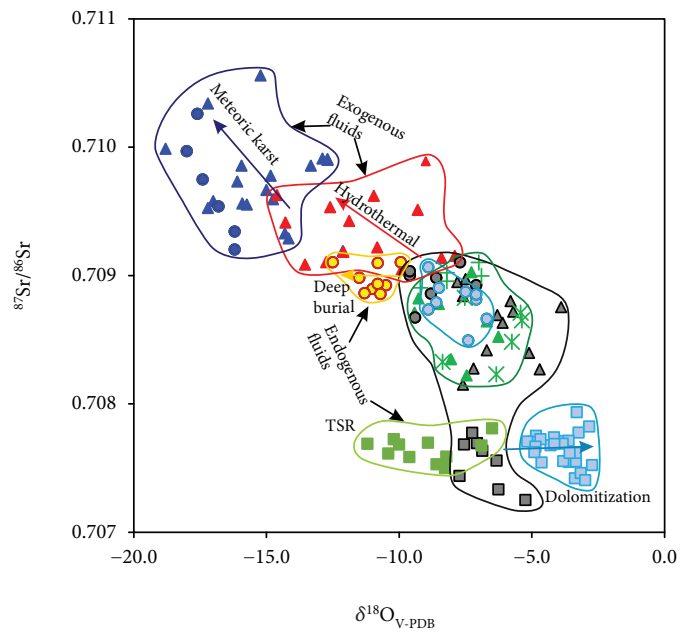

$\Delta$ Limestone $(\mathrm{O})$ in Tarim Basin

* Seawater calcite $(\mathrm{O})$ in Tarim Basin

- Shallow burial formation water calcite $(\mathrm{O})$ in Tarim Basin

- Meteoric megacrystalline calcite $(\mathrm{O})$ in Tarim Basin

- Hydrothermal calcite $(\mathrm{O})$ in Tarim Basin

- Limestone (O) in Sichuan Basin

+ Seawater calcite $(\mathrm{O})$ in Sichuan Basin

- Deep burial formation water calcite (O) in Sichuan Basin

- Meteoric megacrystalline calcite $(\mathrm{O})$ in Sichuan Basin

- Crypto/fine crystalline dolomite $\left(\mathrm{O}_{1}\right)$ in Sichuan Basin

- Limestone $(\mathrm{T}, \mathrm{f})$ in Sichuan Basin

- Crypto/fine crystalline dolomite $\left(\mathrm{T}_{1} \mathrm{f}\right)$ in Sichuan Basin

- TSR calcite $\left(\mathrm{T}_{1} \mathrm{f}\right)$ in Sichuan Basin

FIGURE 5: Strontium and oxygen isotope compositions to identify different fluid alterations in the deep marine carbonate reservoirs.

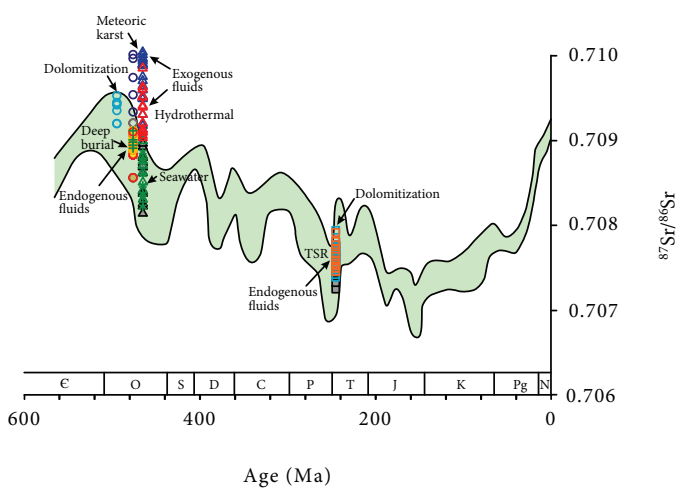

\footnotetext{
$\Delta$ Limestone $(\mathrm{O})$ in Tarim Basin

* Seawater calcite $(\mathrm{O})$ in Tarim Basin

$\Delta$ Shallow burial formation water calcite $(\mathrm{O})$ in Tarim Basin

$\Delta$ Meteoric megacrystalline calcite $(\mathrm{O})$ in Tarim Basin

$\triangle$ Hydrothermal calcite $(\mathrm{O})$ in Tarim Basin

- Limestone $(\mathrm{O})$ in Sichuan Basin

+ Seawater calcite $(\mathrm{O})$ in Sichuan Basin

- Deep burial formation water calcite $(\mathrm{O})$ in Sichuan Basin

- Meteoric megacrystalline calcite $(\mathrm{O})$ in Sichuan Basin

- Crypto/fine crystalline dolomite $\left(\mathrm{O}_{1}\right)$ in Sichuan Basin

- Limestone $(\mathrm{T}, \mathrm{f})$ in Sichuan Basin

口 Crypto/fine crystalline dolomite $\left(\mathrm{T}_{1} \mathrm{f}\right)$ in Sichuan Basin

- TSR calcite $(\mathrm{T}, \mathrm{f})$ in Sichuan Basin
}

FIgURe 6: Strontium isotope ratios to identify different fluid alterations in the deep marine carbonate reservoirs (the seawater ${ }^{87} \mathrm{Sr} /{ }^{86} \mathrm{Sr}$ ratios from the Cambrian to present are based on Veizer et al.'s report [26]).

weak dark red cathodoluminescence under cathodic rays (Figures 3(c) and 3(d)).

Calcite cement precipitated from seawater usually has isotopic compositions similar to those of marine limestones. As shown in Figures 4-6, the seawater calcite samples and marine limestone samples are distributed in the same areas. Because the formation of seawater aragonite mainly occurs in the near-surface environment and aragonite quickly transforms to annular fibrous calcite, most of the fluid inclusions in the calcite contain a homogeneous liquid phase at room temperature. For a few fluid inclusions, homogenization temperatures could be measured. The homogenization temperatures in the calcite from the Ordovician seawater are relatively low. The highest temperature is $49.3^{\circ} \mathrm{C}$, with an average of $43.6^{\circ} \mathrm{C}$. According to the diagram of fluid temperatures and oxygen isotopes of calcite, the oxygen isotopes of the fluid for the calcite cement (green " $*$ " and "+" samples) in the Ordovician limestone are within the range of the CambrianOrdovician seawater, indicating that the calcite cement was precipitated from seawater (Figure 7).

5.1.3. Deep Burial Formation Water. Carbonate rocks gradually entered the deep burial diagenetic stage after sedimentation in seawater. During the deep burial diagenetic evolution, calcite cement precipitated from formation water (Figure 2(e)). The calcite was usually coarse crystalline equiaxial granular calcite (Figures 3(c) and 3(d)), which shows red cathodoluminescence under cathode rays (Figure 3(d)). Deep burial calcite usually filled in the residual spaces after the annular radial calcites formed by early-stage seawater cementation (Figure 3(c)). 


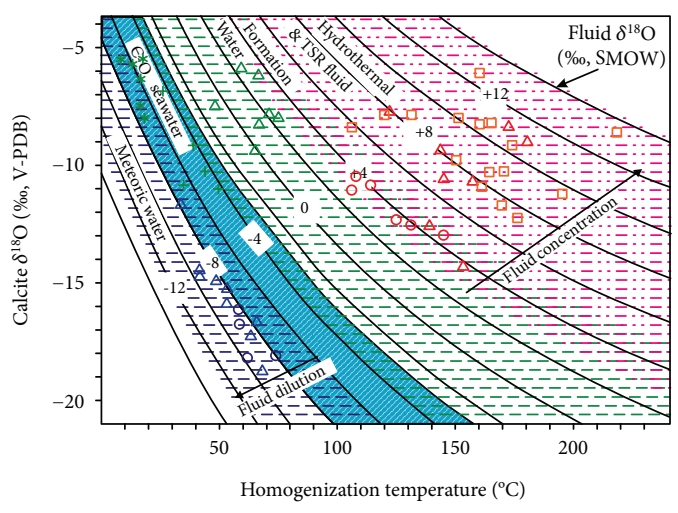

* Seawater calcite $(\mathrm{O})$ in Tarim Basin

$\Delta$ Shallow burial formation water calcite $(\mathrm{O})$ in Tarim Basin $\Delta$ Meteoric megacrystalline calcite $(\mathrm{O})$ in Tarim Basin

$\Delta$ Hydrothermal calcite $(\mathrm{O})$ in Tarim Basin

+ Seawater calcite $(\mathrm{O})$ in Sichuan Basin

- Deep burial formation water calcite $(\mathrm{O})$ in Sichuan Basi

- Meteoric megacrystalline calcite $(\mathrm{O})$ in Sichuan Basin

- TSR calcite $(\mathrm{T}, \mathrm{f})$ in Sichuan Basin

FIGURE 7: Relationships between oxygen isotopes of fluid, oxygen isotopes of calcite, and homogenization temperatures of fluid inclusions in calcite.

During the process of gradual deep burial, the formation water that was originally seawater enclosed in pores of carbonate sediments continuously reacted with the surrounding carbonates and was gradually concentrated into formation brine with high temperature and high salinity. Due to long-term interactions, the formation water gradually reached geochemical equilibrium with the surrounding carbonate rocks. Therefore, its carbon and strontium isotope compositions are basically the same as those of surrounding carbonates (Figures 4 and 6). However, under the influence of the oxygen isotope fractionation effect between calcite and fluid at high temperature $\left(1000 \ln \alpha_{\left(\mathrm{CaCO}_{3}-\mathrm{H}_{2} \mathrm{O}\right)}=2.78 \times\left(10^{6} T^{-2}\right)-3.39\right)$ [40], the oxygen isotope compositions of the calcite cement from formation water in the deeply buried strata are significantly light, with an average $\delta^{18} \mathrm{O}_{\mathrm{V} \text {-PDB }}$ value of $-11.3 \%$ o and a minimum of $-12.6 \%$. The homogeneous temperatures of the fluid inclusions in the calcite are 101.2 to $145.6^{\circ} \mathrm{C}$. According to the relationship between fluid temperature and oxygen isotope of calcite, the $\delta^{18} \mathrm{O}_{\mathrm{SMOW}}$ of the fluid for the calcite (red " $O$ " samples) is approximately $+4 \%$ o (Figure 7), indicating that the fluid is concentrated deep burial formation water.

5.1.4. Meteoric Water. Influenced by intense tectonic uplift, carbonate rocks were exposed above the ground surface and subjected to meteoric water karstification, leading to the formation of karst fractures and cave reservoirs [41, 42]. These reservoirs were widely developed in the Ordovician rocks of the Tarim Basin and Ordos Basin.

Meteoric water could also precipitate calcite cement in preexisting karst fractures and caves (Figures 2(a) and $2(b))$. The calcite precipitated in the vadose zone is generally in crescent or suspended shapes, and that in the phreatic zone is in annular bladed shapes, equiaxial granular mosaic shapes [39], or megacrystal shapes in large karst caves. For example, megacrystalline calcite was observed filling karst caves (Figures 2(a) and 2(b)) in the T904 and TS3 wells in the Tarim Basin. In some dissolution vugs, erosive residue was found to accumulate at the bottom of the vugs to form bottom-identifying structures and the vugs were filled with granular calcite precipitated from meteoric water. The calcite did not emit cathodoluminescence under cathode ray irradiation (Figures $3(\mathrm{a})$ and $3(\mathrm{~b})$ ).

Due to evaporative fractionation of the oxygen isotopes, meteoric water usually has very light oxygen isotope compositions and consequently, calcite precipitated from the meteoric water also has very light oxygen isotope compositions [43] (Figure 4). The average value of the $\delta^{18} \mathrm{O}_{\mathrm{V}-\mathrm{PDB}}$ of the meteoric calcite is $-15.4 \%$, and the lowest value is $-18.8 \%$. The carbon isotope composition of calcite is determined by $\mathrm{CO}_{3}{ }^{2-}$ or $\mathrm{CO}_{2}$ in solution, which may be a combination of organic and inorganic materials. In general, organic carbonate $\left(\mathrm{CO}_{3}{ }^{2-}\right)$ or $\mathrm{CO}_{2}$ has low carbon isotope compositions and its $\delta^{13} \mathrm{C}$ is generally lower than $-20 \%$ [44]. Meteoric water can obtain organic $\mathrm{CO}_{2} / \mathrm{CO}_{3}{ }^{2}$-, which is derived from biological processes or the oxidation of organic matter in the karst weathering crust. The meteoric calcite incorporates the organic $\mathrm{CO}_{2} / \mathrm{CO}_{3}{ }^{2}$ - and consequently has light carbon isotope compositions (Figure 4).

Felsic clastic rocks and mudstones usually have high ${ }^{87} \mathrm{Sr} /{ }^{86} \mathrm{Sr}$ ratios because they contain more radiogenic ${ }^{87} \mathrm{Sr}$. The ${ }^{87} \mathrm{Sr} /{ }^{86} \mathrm{Sr}$ ratios of silicate clastic materials separated from the late Cenozoic sediments of the Alpha Ridge in the central Atlantic Ocean range from 0.713100 to 0.725100 [45]. The weathering and leaching of sandy and argillaceous debris at the surface can lead to enrichment in ${ }^{87} \mathrm{Sr}$ and high ${ }^{87} \mathrm{Sr} /{ }^{86} \mathrm{Sr}$ ratios in meteoric water. The calcite precipitated from the meteoric water also has high ${ }^{87} \mathrm{Sr} /{ }^{86} \mathrm{Sr}$ ratios (Figure 6). The average ratio of ${ }^{87} \mathrm{Sr} /{ }^{86} \mathrm{Sr}$ of the meteoric calcite is 0.709735 , and the highest is 0.710558 .

After dissolving carbonates on the surface, meteoric water migrated downward along fractures and cave passage and then formed cementation of megacrystalline calcite due to changes in temperature and pressure. The homogenization temperatures of fluid inclusions in meteoric megacrystalline calcite are generally low, ranging from 35.5 to $75.3^{\circ} \mathrm{C}$, with an average of $57.5^{\circ} \mathrm{C}$. According to the relationship between fluid temperature and oxygen isotopes of calcite, the $\delta^{18} \mathrm{O}_{\text {SMOW }}$ values of the fluid for megacrystalline calcite (blue " $\triangle$ " samples) lie between $-10 \%$ and $-8 \%$, indicating that the fluid is meteoric water (Figure 7).

5.1.5. Fault-Hydrothermal Fluid. During burial diagenesis, carbonate rocks were widely altered by hydrothermal fluid migrating along faults. Calcite from hydrothermal fluid usually occurred as calcite veins in fractures (Figure 2(c)) and was often accompanied by hydrothermal quartz, dolomite, pyrite, sphalerite, and fluorite (Figure 2(d)).

The hydrothermal fluid generally had higher temperature and pressure than the strata through which it flowed and had abundant active components, such as $\mathrm{CO}_{2}, \mathrm{CO}_{3}{ }^{2-}, \mathrm{Ca}^{2+}$, and $\mathrm{Mg}^{2+}$. When migrating upward along faults, the hydrothermal fluid disrupted the physicochemical balance between the formation water and surrounding rocks and thus caused 
significant water-rock interactions [46]. The results of waterrock interactions in the carbonate reservoirs were mainly dissolution of carbonates, precipitation of carbonate minerals, recrystallization [47], and hydrothermal dolomitization [31]. Faults and fractures constituted channels for hydrothermal fluid migration. Along the channels, hydrothermal fluid dissolved and altered carbonate reservoirs.

Large-scale hydrothermal activity in the basin required an effective driving force. The heat released by magmatic and volcanic activity in the basin was an important driving force for the migration of hydrothermal fluid to shallow strata. The Tarim Basin experienced four geothermal events [48], among which the Permian magmatic activity was most intense and could trigger and drive basin-wide hydrothermal migration. The Tongwan and Emei magmatism and volcanism in the late Sinian-early Cambrian and Permian affected the hydrothermal activity in the Sichuan Basin $[49,50]$.

Based on the fractionation of oxygen isotopes between calcite and fluid [40], the composition of the oxygen isotopes in calcite was controlled by the temperature of the fluid during precipitation. If the hydrothermal fluid had relatively high temperature, the calcite would consequently have light oxygen isotope composition (Figure 4). The average $\delta^{18} \mathrm{O}_{\mathrm{V}-\mathrm{PDB}}$ value of the hydrothermal calcite is $-10.8 \%$, and the minimum is $-14.6 \%$. During migration from deep to shallow strata along the fault system, the hydrothermal fluid could obtain radiogenic ${ }^{87} \mathrm{Sr}$ from deep basement or clastic rock strata and thus has high ${ }^{87} \mathrm{Sr} /{ }^{86} \mathrm{Sr}$ ratios (Figure 6). The average ${ }^{87} \mathrm{Sr} /{ }^{86} \mathrm{Sr}$ ratio is 0.709353 , and the maximum is 0.709891 .

The range of homogenization temperatures of the fluid inclusions in calcite veins is from 108.7 to $198.7^{\circ} \mathrm{C}$, with an average of $154.3^{\circ} \mathrm{C}$ (Table 1). Most of the homogenization temperatures are higher than the burial temperatures of surrounding carbonate strata, indicating that the fluid is hydrothermal fluid. According to the oxygen isotope fractionation relationship between calcite and fluid, the calcite veins in fractures (red " $\triangle$ " samples) are located in the range of deep hydrothermal fluid (Figure 7).

5.1.6. Deep Burial TSR-Derived Fluid. TSR is generally defined as the reduction of sulfate (sulfate minerals or sulfate in fluid) in strata at high temperature [10,51]. By consuming organic matter (gaseous or liquid hydrocarbons), $\mathrm{S}^{6+}$ in the $\mathrm{SO}_{4}{ }^{2-}$ state is reduced into $\mathrm{S}^{0}$ or $\mathrm{S}^{2-}$. Its reaction equation is as follows:

$$
\mathrm{CaSO}_{4}+\mathrm{C}_{n} \mathrm{H}_{m} \text { (hydrocarbons) } \rightarrow \mathrm{CaCO}_{3}+\mathrm{H}_{2} \mathrm{~S}+\mathrm{CO}_{2}+\mathrm{H}_{2} \mathrm{O}
$$

The formula shows that $\mathrm{CO}_{2}$ and $\mathrm{CO}_{3}{ }^{2-}$ in $\mathrm{CaCO}_{3}$ formed during the TSR process come from hydrocarbons and therefore have very light carbon isotope compositions.

Previous studies have shown that TSR occurred in the Ordovician carbonate reservoirs in the Tarim Basin and in the Sinian, Cambrian, Permian, and Triassic carbonate reservoirs in the Sichuan Basin. The natural gas in the deep carbonate reservoirs with TSR contains large amounts of $\mathrm{H}_{2} \mathrm{~S}$ and $\mathrm{CO}_{2}[52]$.
Calcite precipitated from TSR-derived fluid is in coarse bladed or granular crystalline form (Figures 2(e) and 3(f)) and is often accompanied by granular TSR pyrite and hot asphalt. The calcite is characterized by remarkably light carbon isotope compositions with an average $\delta^{13} \mathrm{C}_{\mathrm{V}-\mathrm{PDB}}$ of $-11.5 \%$ and a minimum value of $-18.9 \%$ (Figure 4 ). This effect appears because the $\mathrm{CO}_{3}{ }^{2-}$ in TSR calcite comes from the organic matter consumed by TSR. TSR occurred inside the carbonate strata, and the TSR-related fluid was also activated within the carbonate strata. Therefore, the ${ }^{87} \mathrm{Sr} /{ }^{86} \mathrm{Sr}$ ratios of TSR calcite should be similar to those of the carbonate strata. Consequently, the ${ }^{87} \mathrm{Sr} /{ }^{86} \mathrm{Sr}$ ratios of the TSR calcite in the Triassic Feixianguan Formation are similar to those of the Feixianguan Formation limestones (Figure 6).

High temperature is generally required for $\operatorname{TSR}[53,54]$. The onset temperature for TSR involving $\mathrm{CH}_{4}$ may be as high as $200^{\circ} \mathrm{C}$; however, geological observations have suggested that TSR may start at much lower temperatures from 80 to $180^{\circ} \mathrm{C}$ [55]. The homogenization temperatures of the fluid inclusions in TSR calcite are between 134.1 and $218.2^{\circ} \mathrm{C}$ with an average temperature of $169.2^{\circ} \mathrm{C}$, which satisfies the hightemperature condition for TSR. According to the relationship between oxygen isotopes and homogenization temperatures, TSR-related fluid (red yellow " $\square$ " samples), similar to the deep hydrothermal fluid (red " $\triangle$ " samples), is concentrated fluid with heavy oxygen isotope compositions (Figure 7).

5.2. Evolution of Tectonic-Fluid Environments. Fluid alterations during diagenesis were closely related to specific tectonic or burial backgrounds. The tectonic and burial backgrounds determined what kind of fluid alteration the carbonate rocks would undergo at a certain stage of evolution. Just after sedimentation, the carbonates underwent seawater alteration, mainly including cementation and dolomitization in evaporating seawater. During the deep burial process, the high-salinity formation brine could interact with surrounding carbonates continuously. Due to intense tectonic uplift, the carbonate rocks were exposed above the surface and were consequently dissolved and transformed by meteoric water. During burial evolution, hydrothermal fluids could migrate upward from deep to shallow strata along faults and fractures, leading to significant dissolution of the carbonates. In the deep burial stage, $\mathrm{SO}_{4}{ }^{2-}$ (in formation water or anhydrite) in carbonate strata underwent TSR to produce $\mathrm{CO}_{2}$ and $\mathrm{H}_{2} \mathrm{~S}$. The resulting fluids rich in $\mathrm{CO}_{2}$ and $\mathrm{H}_{2} \mathrm{~S}$ had a strong ability to dissolve carbonate rocks.

The diagenesis and fluid alterations in the deep carbonate reservoirs were commonly accompanied by organic matter (Figure 4). In the meteoric karst process, microbial activity or humification of organic matter was involved. In the process of hydrothermal alteration along deep faults, hydrocarbon generation occurred from the maturation of organic matter followed by migration and accumulation to form reservoirs. In the TSR process, hydrocarbons were consumed and oil was cracked into gas. From the stages of meteoric karst to hydrothermal dissolution to TSR alteration, the 
degree of thermal evolution of organic matter and the intensity of organic matter participation gradually increased. As a result, the carbon isotope compositions of the resultant calcite/dolomite cement became increasingly lighter.

5.3. Endogenous and Exogenous Fluids. In the diagenetic evolution process, carbonate rocks were subjected to alterations by various fluids. The fluids could originate inside or outside of the carbonate strata and are consequently termed endogenous or exogenous fluid, respectively. Deep burial formation water and TSR-derived fluid are endogenous fluids. The strontium isotope compositions of calcite from endogenous fluids are generally consistent with those of surrounding carbonate rocks. Meteoric water and hydrothermal fluid are exogenous fluids. The carbon, oxygen, and strontium isotope compositions of calcite from exogenous fluids are significantly different from those of surrounding carbonate rocks. The fluids can usually obtain more ${ }^{87} \mathrm{Sr}$ from clastic debris and thus have higher ${ }^{87} \mathrm{Sr} /{ }^{86} \mathrm{Sr}$ ratios.

\subsection{Development Mechanism of Deep Carbonate Reservoirs.} Based on the tectonic evolution background and types of fluid alteration in the deep lower Paleozoic carbonate reservoirs in Tarim Basin, Sichuan Basin, and Ordos Basin, we conclude that three major tectonic-fluid environments have significantly influenced the development of deep carbonate reservoirs, namely, the tectonic uplift-meteoric water, fault-hydrothermal fluid, and deep burial-TSRderived fluid environments, each having different flow patterns and dissolution models.

\subsubsection{Tectonic Uplift-Meteoric Water Environment. The} Ordovician limestones in the Tarim Basin, the Ordovician Majiagou Formation limestones in the Ordos Basin, and the Sinian Dengying Formation dolomites in the Sichuan Basin have all undergone intense tectonic uplift-meteoric water karst alteration, leading to the formation of large-scale carbonate reservoirs with karst fractures and caves [56]. The karst reservoirs in the Ordovician carbonates in both the Tarim Basin and Ordos Basin are typical examples to be discussed in detail.

(1) Karst Reservoir in the Tarim Basin. A huge oil field in a karst reservoir is the Tahe oil field in the Akekule uplift, northern Tarim Basin. The main oil- and gas-producing layer in the Tahe oil field is the karst cave reservoir developed near the karst unconformity surface. The karst caves show bead-like reflections on the seismic profile (Figure 8).

The Ordovician carbonate rocks in the Akekule uplift had been subjected to meteoric water karstification in the middle Caledonian (late Early Ordovician to Late Ordovician), early Hercynian (Devonian), and late Hercynian (late Permian). The karstification in the middle Caledonian included several episodes, resulting in several karst unconformities, for example, the karst unconformity between the Middle Ordovician Yijianfang Formation $\left(\mathrm{O}_{2} \mathrm{yj}\right)$ and the Upper Ordovician Chalbak Formation $\left(\mathrm{O}_{3} \mathrm{q}\right)$ and the karst unconformity between the Upper Ordovician Liangritag
Formation $\left(\mathrm{O}_{3} \mathrm{l}\right)$ and the Santamu Formation $\left(\mathrm{O}_{3} \mathrm{~s}\right)$. The early Hercynian karstification that occurred in the Late Devonian and early Carboniferous was most intense. During this period, karstification occurred in almost all the Akekule uplift, and as a result, the Middle and Upper Ordovician carbonates were eroded, leading to an unconformity between the Middle-Lower Ordovician and the Carboniferous. In the late Hercynian, the tectonic high and karstification zone were mainly located in the Yuqi area, northeastern Akekule uplift, and as a result, a karstification unconformity between the Middle-Lower Ordovician and Triassic was formed.

Controlled by thermodynamic and kinetic factors, karst caves related to meteoric karstification were mainly developed at a limited depth under the karst unconformity surface. Below the karst cave zone, calcite would precipitate and fill existing reservoir spaces [57]. In the karst area of high tectonic uplift, meteoric water could strongly dissolve carbonate rocks because it was highly unsaturated with respect to carbonate and the flow rate was very large. A large number of drilling wells reveal that the karst caves were dominantly developed within a depth of $200 \mathrm{~m}$ below the unconformity surface but could occasionally occur at a depth of $1100 \mathrm{~m}$ [58]. In the karst slope-depression area, as the meteoric water migrated downward, calcite would precipitate and fill existing fractures or caves because the meteoric water gradually reached its saturation state for carbonate with a decrease in the flow rate and an increase in temperature and pressure $[57,59]$ (Figure 8(a)).

Taking the profile from the S81 to TP20 well in the Tahe oil field as an example (Figure 8(a)), the S81 well is located in the high uplift area and the TP20 well is in the depression area. In seismic profiles, the karst caves in the Ordovician carbonate reservoir usually show bead-like reflections, which are the targets for oil and gas drilling. The karst caves with bead-like reflections at the bottom of the T738 and AD5 wells located in the uplift area have not been filled by calcite, so that they are good oil-producing caves (Figures 8(b) and $8(c))$. However, the karst caves with bead-like reflections in the AD3 well located in the depression area have been completely filled with megacrystalline calcite (Figures 8(d) and $8(\mathrm{e}))$. The calcite fill in the karst caves caused failure in hydrocarbon exploration.

(2) Karst Reservoir in the Ordos Basin. In the Ordos Basin, the Ordovician sequences are dominated by marine carbonates and include four formations: from bottom to top, the Yeli Formation including dolomite with intercalated beds of dolomitic shale; the Liangjiashan Formation including chert band-bearing dolostone with intercalated beds of argillaceous dolostone; the Majiagou Formation including dolostone, limestone, and evaporite; and the Fengfeng Formation including massive limestone [41].

During the later Caledonian orogeny (from the end of the Ordovician to the early Carboniferous) [56], the Majiagou Formation carbonates were uplifted and exposed to subaerial environments, leading to the development of meteoric karst. As a result, the Majiagou Formation is unconformably overlain by the Carboniferous Benxi 


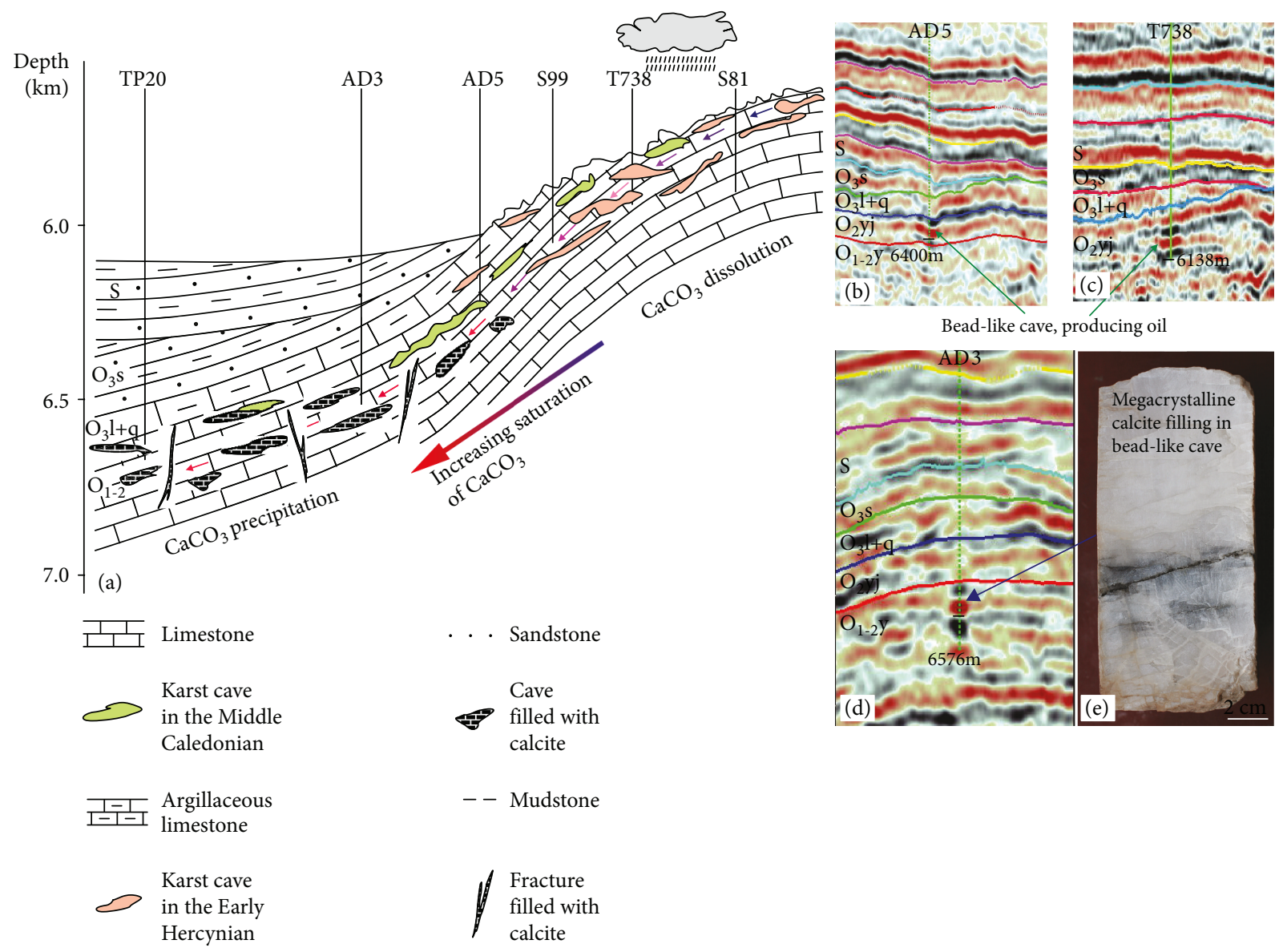

Figure 8: Developing model of dissolution and cementation in the Ordovician carbonate reservoir in the tectonic uplift-meteoric water environment in the Tahe oil field, Tarim Basin. (a) Dissolution-cementation model. (b) Seismic profile crossing AD5 well located in the uplift area shows karst cave with bead-like reflection, and the karst cave produced oil. (c) Seismic profile crossing T738 well located in the slope area shows karst cave with bead-like reflection, and the karst cave produced oil. (d) Seismic profile crossing AD3 well located in the depression area shows karst cave with bead reflection, but the karst cave was filled with calcite and did not produce oil. (e) $2.7 \mathrm{~m}$ thick megacrystalline calcite in the karst cave in AD3 well.

Formation. Above the unconformity, the lower part of the Benxi Formation formed as a residual deposit from the weathering of Ordovician carbonate rocks and consists of kaolinitic mudstone, allite, and limonite [41]. Most of the Majiagou Formation carbonates have been altered to karst breccia, dominated by mosaic and chaotic breccia, as well as fractured units. Due to a paleotopography high in the west and low in the east, a large-scale karst highland was developed in the central and eastern Ordos Basin during the early karst stage [60].

Heavy leaching and dissolution by meteoric water led to the formation of a large quantity of reservoir spaces, including karst caves, vugs, and fractures, in the Majiagou Formation carbonates (Figure 9). The Majiagou Formation carbonates contained large amounts of anhydrite; therefore, moldic pores after dissolution of anhydrite during karst development contributed a large proportion of reservoir space. Due to long-term exposure above the surface and weathering, some of the karst caves, vugs, and fractures developed in the early karst stage were filled by sediments in the Benxi stage [61]. According to well M15 in the eastern and well Z65 in the central Ordos Basin, the thickness of the
Majiagou Formation paleokarst reservoir unit is more than $50 \mathrm{~m}$ [60]. The oil and gas fields associated with the Majiagou Formation karst carbonate reservoirs, e.g., the Jingbian and Daniudi gas fields, are mainly distributed in the east and center of the Ordos Basin.

5.4.2. Fault-Hydrothermal Environment. The Ordovician carbonates in the Shuntuo area, central Tarim Basin, have been subjected to significant fault-hydrothermal fluid alteration. A series of NE-trending strike-slip faults cutting down into the basin basement developed in the Ordovician and became conduits for migration of the deep hydrothermal fluid. The basement strike-slip faults began to be active in the middle Caledonian period. The strike-slip faults were most active in the early Hercynian period, forming a series of flower-like structures in the Ordovician carbonates. From the end of the Hercynian to the Indosinian, the strike-slip faults continued to open and became channels for hydrothermal fluid.

Tectonic cracks and hydrothermal alterations along strike-slip faults were the main factors in the formation of Ordovician reservoirs in the Shuntuo area [24]. Due to the 


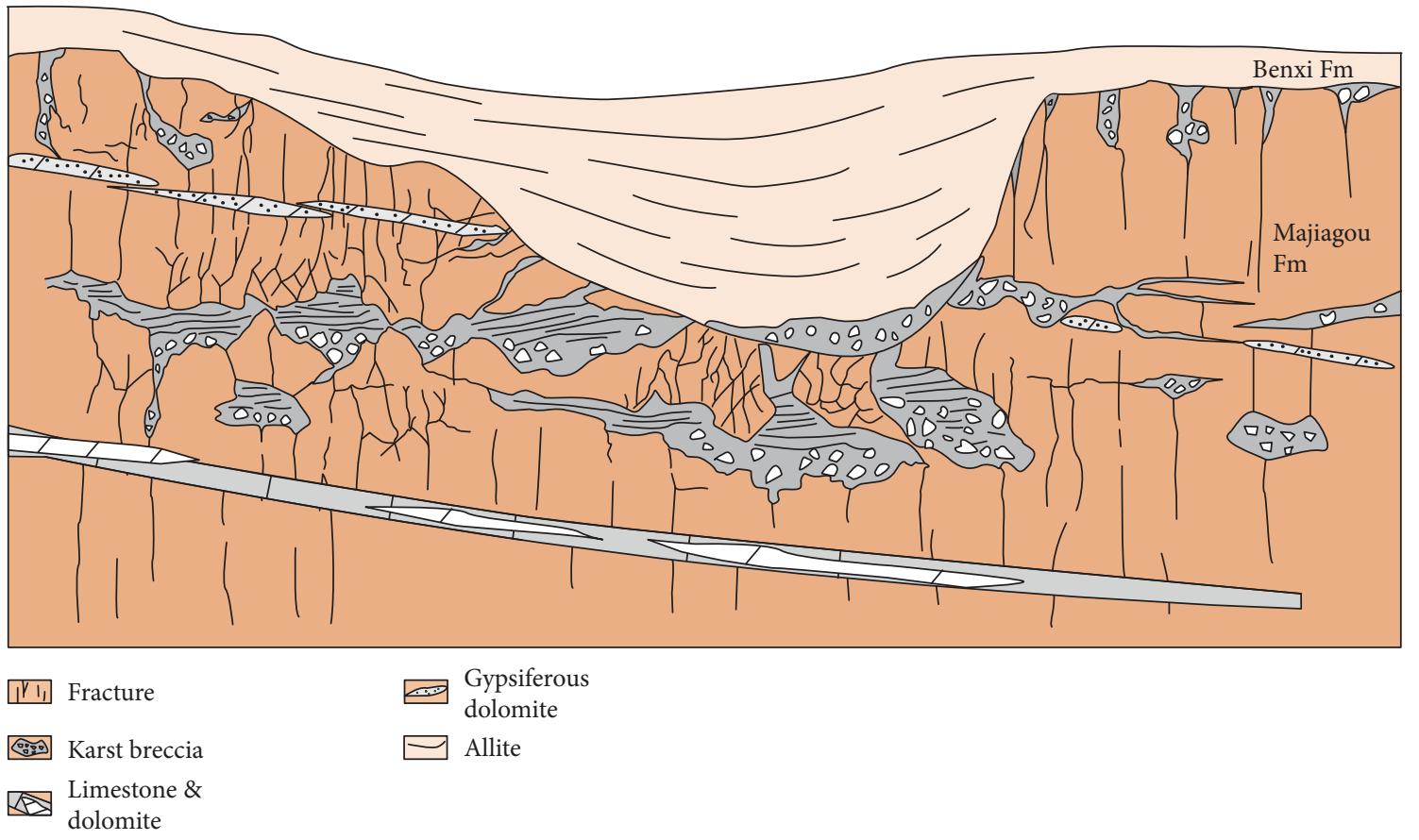

Figure 9: Characteristics of the Ordovician carbonate karstic reservoirs in Ordos Basin. The karst reservoir model was modified from reference [61].

continuous development of strike-slip faults, the Ordovician carbonate rocks near the fault zone underwent significant tectonic fracturing, as shown by structural breccias of varying sizes in the drill cores. Many wells, such as Shunnan 4, Shunbei 1-2H, Shunbei 1-3CH, and Shunbei 1-4H, met holes during drilling, indicating the existence of a fracturerelated cavity system.

The basement strike-slip faults were important channels for deep hydrothermal fluids (Figure 10). Several wells in the Shuntuo area demonstrated typical petrographic phenomena, such as silicification, cluster quartz, hydrothermal dolomite, calcite, and fluorite, implying the influence of the deep hydrothermal fluid. Particularly in the SN4 well, strong silicification related to hydrothermal in the Ordovician Yingshan Formation limestone reservoir (6668-6681 m) was revealed. The porosity of the silicified reservoir is 3$20.5 \%$, much higher than that of the limestone reservoir (porosity of $1.4-1.6 \%$ ) without hydrothermal alteration [62]. A high-yielding gas flow of $45.8 \times 10^{4} \mathrm{~m}^{3} /$ day was produced from the silicified reservoir. Under the influence of deep fault-hydrothermal fluids, high-quality carbonate reservoirs could potentially develop downward continuously into ultradeep carbonate strata. The potential was proved by well TS1 in the Akekule uplift, which discovered a highquality dolomite reservoir with porosity as high as $9.1 \%$ at depths as great as $8408 \mathrm{~m}$ [63].

Magmatic/volcanic activity provided a thermal driving force for the migration of deep hydrothermal fluids from deep strata to Ordovician carbonates. The Tarim Basin experienced four geothermal events during the Sinian-Cambrian, Early Ordovician, Permian, and Cretaceous periods [48], of which the Permian magmatism was the strongest and widely distributed in the Tarim Basin. An intrusive diabase with a thickness of $44 \mathrm{~m}$ was drilled by the ST1 well in the Ordovician Qiaerbake Formation (Figure 10). Seismic profiles showed a large number of igneous intrusive bodies in the area near the ST1 well.

Basement strike-slip faults played important roles not only in reservoir development but also in hydrocarbon accumulation. The major NE-trending strike-slip faults cut down to the bottom of the Cambrian and thus became a key channel for the vertical migration of oil and gas from the middlelower Cambrian source rocks (Figure 10). Therefore, along the basement strike-slip fault zone, a series of drilling wells have obtained high-yield oil and gas flow in the deep Ordovician carbonate reservoirs. The oil and gas production layers are commonly below $7000 \mathrm{~m}$. For example, the ST1 well revealed a high-quality gas-rich reservoir (with a gas yield of $35.8 \times 10^{4} \mathrm{~m}^{3} /$ day) at $7658-7874 \mathrm{~m}$ in the Yijianfang and Yingshan formations.

5.4.3. Deep Burial-TSR Environment. The deep marine carbonate strata in the Sichuan Basin have high burial temperatures, contain large amounts of oil and gas, and are rich in anhydrite, thus meeting the necessary conditions for the occurrence of TSR. Therefore, TSR occurred extensively in several carbonate reservoirs in the Sinian Dengying Formation, Cambrian Longwangmiao Formation [12], Permian Changxing Formation, and Triassic Feixianguan Formation $[64,65]$, resulting in high concentrations of $\mathrm{H}_{2} \mathrm{~S}$ and $\mathrm{CO}_{2}$ in natural gas.

The Permian Changxing Formation and Lower Triassic Feixianguan Formation dolomite reservoirs in the Puguang and Yuanba gas fields, northern Sichuan Basin, experienced strong deep burial-TSR-derived fluid environments and consequently developed into high-quality porous dolomite 


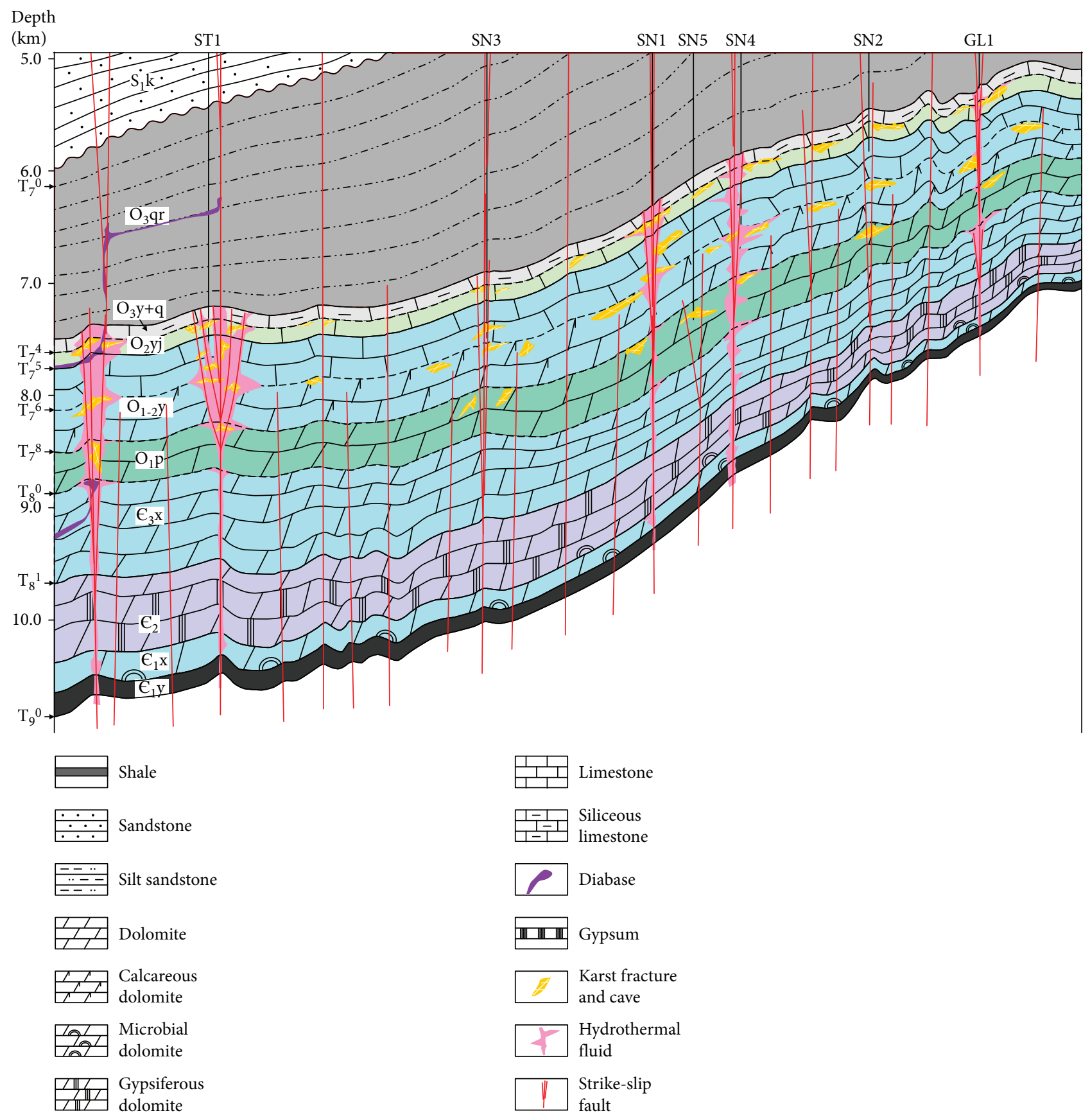

FIgURE 10: Crossing well profile of the deep Ordovician carbonate reservoir influenced by the fault-hydrothermal alteration in the Shunnan area, Tarim Basin.

reservoirs $[66,67]$. The Changxing and Feixianguan Formation reef-shoal dolomite reservoirs entered the continuous burial diagenetic stage after sedimentation. Before uplift in the Himalayan period (from the Cretaceous), the burial depth reached more than $7000 \mathrm{~m}$ and the burial temperature was higher than $180^{\circ} \mathrm{C}$ (Figure 11). With high burial temperatures, large amounts of organic matter (crude oil and natural gas), and the presence of anhydrite, TSR took place extensively, resulting in increasing concentrations of $\mathrm{H}_{2} \mathrm{~S}$ and $\mathrm{CO}_{2}$ in the natural gas. The concentrations of $\mathrm{H}_{2} \mathrm{~S}$ and $\mathrm{CO}_{2}$ in wells such as Puguang 5, Puguang 2, Puguang 4, and Puguang 3 are as high as $5.10 \%$ and $7.86 \%, 16.80 \%$ and
$7.89 \%, 14.27 \%$ and $17.24 \%$, and $62.17 \%$ and $15.32 \%$, respectively [12] (Figure 11(b)).

Hao et al. [11] believed that the high contents of $\mathrm{H}_{2} \mathrm{~S}$ and $\mathrm{CO}_{2}$ related to TSR would not cause dissolution of the carbonate reservoir; on the contrary, TSR might lead to the precipitation of calcite. In fact, the $\mathrm{Ca}^{2+}$ in calcite came from anhydrite consumed by TSR; therefore, the precipitation of calcite would not lead to a decrease in pore space. Ehrenberg et al. [68] calculated the amount of fluid required to generate porosity and found that $27000 \mathrm{~m}^{3}$ fluid is needed to generate $1 \mathrm{~m}^{3}$ dissolution pores in carbonates. The amount of endogenous TSR-derived fluid was very limited due to the lack of 


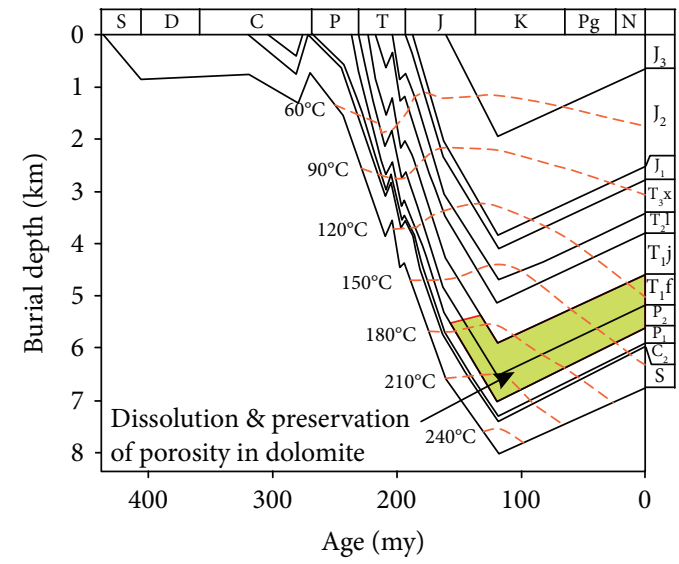

(a) Burial and thermal history of PG2 well

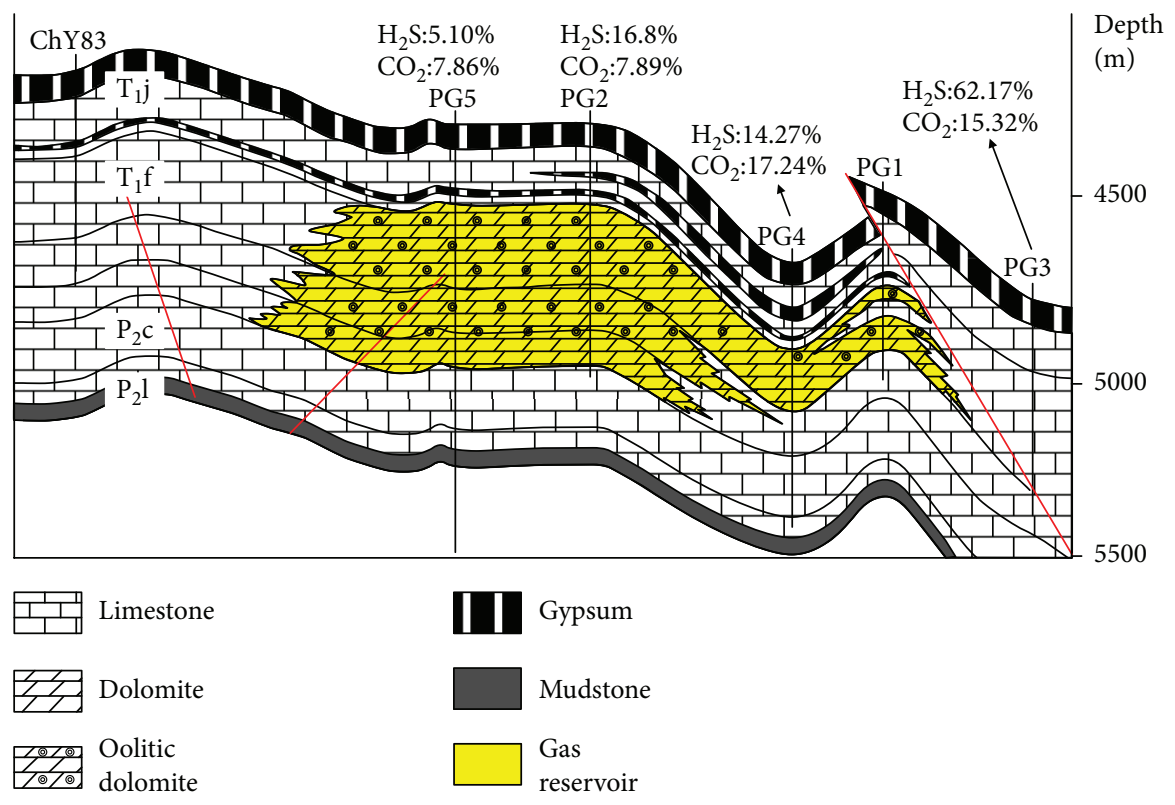

(b) Puguang reservoir

FIgURE 11: The Triassic Feixianguan Formation dolomite reservoir profile affected by deep burial-TSR-derived fluid in the Puguang gas field, Sichuan Basin. (a) Burial history (modified from Liu et al. [12]). (b) Gas reservoir profile (modified from Ma et al. [69]).

inflow and outflow circulation, so no large proportion of new dissolution porosity would form. The numerous dissolution pores in the Lower Triassic dolomite were considered the result of dissolution in the near-surface meteoric karst environment during the syngenetic/quasi-syngenetic stage [11].

Although the TSR-derived fluid might not increase new porosity in the dolomite reservoirs, the acidic fluid with high concentrations of $\mathrm{CO}_{2}$ and $\mathrm{H}_{2} \mathrm{~S}$ should be better for the long-term preservation of porosity because it did not precipitate calcite to fill the existing pores [12]. From the Himalayan (Cretaceous) period, strong tectonic uplift occurred in the Sichuan Basin. For example, the burial depth of the Feixianguan Formation in the Puguang area was uplifted from $7000 \mathrm{~m}$ to $5000 \mathrm{~m}$. In the process of uplift, the dissolution ability of TSR-derived fluid gradually increased with decreasing temperature and pressure, resulting in creation of new porosity. Affected by these factors, the Feixianguan Formation reef and shoal dolomites in the Puguang gas field developed into high-quality dolomite reservoirs with an average porosity of approximately $10 \%$ and many of the reservoirs have porosity greater than $15 \%[11]$.

\section{Conclusions}

(1) On the basis of carbon, oxygen, and strontium isotopes and fluid inclusions, the types of fluid alteration in the deep carbonate reservoirs were accurately identified, including seawater, meteoric water, deep burial formation water, deep hydrothermal fluid, and TSR-derived fluid

(2) Due to equilibrium fractionation of oxygen isotopes between fluid and calcite at high temperature, calcite precipitated from deep burial formation water, 
hydrothermal fluid, and TSR-derived fluid has significantly light oxygen isotope compositions

(3) The carbon isotope compositions of TSR-derived calcite are significantly light due to the involvement of organic $\mathrm{CO}_{2} / \mathrm{CO}_{3}{ }^{2-}$

(4) Deep burial formation water and TSR-derived fluid are endogenous fluids originating in the interior of carbonate strata; consequently, their ${ }^{87} \mathrm{Sr} /{ }^{86} \mathrm{Sr}$ ratios are the same as those of carbonate rocks. Meteoric water and hydrothermal fluid are exogenous fluids originating from outside of carbonate strata, and their ${ }^{87} \mathrm{Sr} /{ }^{86} \mathrm{Sr}$ ratios are significantly higher than those of carbonate rocks

(5) Tectonic uplift-meteoric water, deep faulthydrothermal fluid, and deep burial-TSR-derived fluid environments are the major types of fluid alteration environments for the development of deep carbonate reservoirs

(6) In the tectonic uplift-meteoric water environment, carbonate reservoirs are mainly developed in the zone below the unconformity surface. Under the influence of the deep fault-hydrothermal fluid environment, dissolution and the resulting high-quality dolomite reservoirs can continuously expand downward into ultradeep strata. In the deep burial-TSR environment, the reservoir space can be maintained for a long geological time due to the high concentrations of $\mathrm{H}_{2} \mathrm{~S}$ and $\mathrm{CO}_{2}$

\section{Data Availability}

The data used to support the findings of this study are included within the supplementary information file.

\section{Conflicts of Interest}

The authors declare that they have no conflicts of interest.

\section{Acknowledgments}

This study was financially supported by the Frontier Project of Chinese Academy of Sciences (XDA14010201), National Key R\&D Program of China (2017YFC0603102), and National Natural Science Foundation of China (U1663209 and 41672123).

\section{Supplementary Materials}

The supplementary material file includes a complete list of carbon, oxygen, and strontium isotope data which are used in this article. (Supplementary Materials)

\section{References}

[1] C. A. Sternbach and G. M. Friedman, "Dolomites formed under conditions of deep burial: Hunton Group carbonate rocks (Upper Ordovician to Lower Devonian) in the deep
Anadarko Basin of Oklahoma and Texas," Carbonates and Evaporites, vol. 1, no. 1, pp. 61-73, 1986.

[2] S. J. Mazzullo, "Overview of porosity evolution in carbonate reservoirs," Kansas Geological Society Bulletin, vol. 79, no. 1-2, pp. 20-28, 2004.

[3] E. Hajikazemi, I. S. Al-Aasm, and M. Coniglio, "Subaerial exposure and meteoric diagenesis of the CenomanianTuronian Upper Sarvak Formation, southwestern Iran," Geological Society, London, Special Publications, vol. 330, no. 1, pp. 253-272, 2010.

[4] R. G. Loucks, "Paleocave carbonate reservoirs: origins, burialdepth modifications, spatial complexity, and reservoir implications," AAPG Bulletin, vol. 83, no. 11, pp. 1795-1834, 1999.

[5] Z. Jin, D. Zhu, W. Hu, X. Zhang, J. Zhang, and Y. Song, "Mesogenetic dissolution of the middle Ordovician limestone in the Tahe oilfield of Tarim basin, NW China," Marine and Petroleum Geology, vol. 26, no. 6, pp. 753-763, 2009.

[6] S. J. Mazzullo and P. M. Harris, "Mesogenetic dissolution: its role in porosity development in carbonate reservoirs," $A A P G$ Bulletin, vol. 76, no. 5, pp. 607-620, 1992.

[7] Y. Qian, Y. Chen, Q. Chen, D. You, and S. Zou, "General characteristics of burial dissolution for Ordovician carbonate reservoirs in the northwest of Tazhong area," Acta Petrologica Sinica, vol. 27, no. 3, pp. 59-61, 2006.

[8] D. Lavoie, G. Chi, M. Urbatsch, and W. J. Davis, "Massive dolomitization of a pinnacle reef in the Lower Devonian West Point Formation (Gaspé Peninsula, Quebec): an extreme case of hydrothermal dolomitization through fault-focused circulation of magmatic fluids," AAPG Bulletin, vol. 94, no. 4, pp. 513-531, 2010.

[9] L. B. Smith Jr. and G. R. Davies, "Structurally controlled hydrothermal alteration of carbonate reservoirs: introduction," AAPG Bulletin, vol. 90, no. 11, pp. 1635-1640, 2006.

[10] C. Cai, W. Hu, and R. H. Worden, "Thermochemical sulphate reduction in Cambro-Ordovician carbonates in Central Tarim," Marine and Petroleum Geology, vol. 18, no. 6, pp. 729-741, 2001.

[11] F. Hao, X. Zhang, C. Wang et al., "The fate of $\mathrm{CO}_{2}$ derived from thermochemical sulfate reduction (TSR) and effect of TSR on carbonate porosity and permeability, Sichuan Basin, China," Earth-Science Reviews, vol. 141, pp. 154-177, 2015.

[12] Q. Liu, D. Zhu, Z. Jin, C. Liu, D. Zhang, and Z. He, "Coupled alteration of hydrothermal fluids and thermal sulfate reduction (TSR) in ancient dolomite reservoirs - an example from Sinian Dengying Formation in Sichuan Basin, southern China," Precambrian Research, vol. 285, pp. 39-57, 2016.

[13] T. Zhang, G. S. Ellis, K. S. Wang et al., "Effect of hydrocarbon type on thermochemical sulfate reduction," Organic Geochemistry, vol. 38, no. 6, pp. 897-910, 2007.

[14] Z. He, J. Zhang, Q. Ding et al., "Factors controlling the formation of high-quality deep to ultra-deep carbonate reservoirs," Oil and Gas Geology, vol. 34, no. 4, pp. 633-644, 2017.

[15] A. Shen, W. Zhao, A. Hu, M. She, Y. Chen, and X. Wang, "Major factors controlling the development of marine carbonate reservoirs," Petroleum Exploration and Development, vol. 42, no. 5, pp. 597-608, 2015.

[16] Z. Jin, D. Zhu, W. Hu, X. Zhang, Y. Wang, and X. Yan, "Geological and geochemical signatures of hydrothermal activity and their influence on carbonate reservoir beds in the Tarim Basin," Acta Geologica Sinica, vol. 80, no. 2, pp. 245-253, 2006. 
[17] J. Zhang, W. Hu, Y. Qian et al., "Formation of saddle dolomites in Upper Cambrian carbonates, western Tarim Basin (northwest China): implications for fault-related fluid flow," Marine and Petroleum Geology, vol. 26, no. 8, pp. 14281440, 2009.

[18] W. Hu, Q. Chen, X. Wang, and J. Cao, "REE models for the discrimination of fluids in the formation and evolution of dolomite reservoirs," Oil \& Gas Geology, vol. 31, no. 6, pp. 810-818, 2010.

[19] Z. He, X. Jin, Y. Wo et al., "Hydrocarbon accumulation characteristics and exploration domains of ultradeep marine carbonates in China," China Petroleum Exploration, vol. 21, no. 1, pp. 3-14, 2016.

[20] T. S. Dyman and T. A. Cook, Summary of Deep Oil and Gas Wells in the United States through 1998, U.S. Geological Survey, U.S.A., 2001.

[21] Y. Wang, J. Su, K. Wang, B. Zhang, J. Zhao, and X. Liu, "Distribution and accumulation of global deep oil and gas," Natural Gas Geoscience, vol. 23, no. 3, pp. 526-534, 2012.

[22] C. Jia, D. He, X. Shi, G. Yang, and C. Zhang, "Characteristics of China's oil and gas pool formation in latest geological history," Science in China Series D: Earth Sciences, vol. 49, no. 9, pp. 947-959, 2006.

[23] W. Zhao, A. Shen, A. Hu, J. Zhou, and X. Ni, "A discussion on the geological background of marine carbonate reservoirs development in Tarim, Sichuan and Ordos Basin, China," Acta Petrologica Sinica, vol. 31, no. 11, pp. 3495-3508, 2015.

[24] F. Jiao, "Significance of oil and gas exploration in NE strikeslip fault belts in Shuntuoguole area of Tarim Basin," Oil \& Gas Geology, vol. 38, no. 5, pp. 831-839, 2017.

[25] D. Zhu, Q. Meng, Z. Jin, Q. Liu, and W. Hu, "Formation mechanism of deep Cambrian dolomite reservoirs in the Tarim basin, northwestern China," Marine and Petroleum Geology, vol. 59, no. 1, pp. 232-244, 2015.

[26] J. Veizer, D. Ala, K. Azmy et al., ${ }^{\text {(87 }} \mathrm{Sr} /{ }^{86} \mathrm{Sr}, \delta^{13} \mathrm{C}$ and $\delta^{18} \mathrm{O}$ evolution of Phanerozoic seawater," Chemical Geology, vol. 161, no. 1-3, pp. 59-88, 1999.

[27] L. S. Land, "The isotopic and trace element geochemistry of dolomite: the state of the art," SEPM Special Publication, vol. 28, pp. 87-110, 1980.

[28] H. G. Machel, "Concepts and models of dolomitization: a critical reappraisal," Geological Society, London, Special Publications, vol. 235, no. 1, pp. 7-63, 2004.

[29] J. Warren, "Dolomite: occurrence区evolution and economically important associations," Earth-Science Reviews, vol. 52, no. 13, pp. 1-81, 2000.

[30] R. Wierzbicki, J. J. Dravis, I. Al-Aasm, and N. Harland, "Burial dolomitization and dissolution of upper Jurassic Abenaki platform carbonates, deep Panuke reservoir, Nova Scotia, Canada," AAPG Bulletin, vol. 90, no. 11, pp. 18431861, 2006.

[31] G. R. Davies and L. B. Smith Jr, "Structurally controlled hydrothermal dolomite reservoir facies: an overview," AAPG Bulletin, vol. 90, no. 11, pp. 1641-1690, 2006.

[32] C. Vasconcelos and J. A. McKenzie, "Microbial mediation of modern dolomite precipitation and diagenesis under anoxic conditions (Lagoa Vermelha, Rio de Janeiro, Brazil)," Journal of Sedimentary Research, vol. 67, no. 3, pp. 378-390, 1997.

[33] X.-L. Bai, S.-N. Zhang, Q.-Y. Huang, X.-Q. Ding, and S.Y. Zhang, "Origin of dolomite in the Middle Ordovician peri- tidal platform carbonates in the northern Ordos Basin, western China," Petroleum Science, vol. 13, no. 3, pp. 434-449, 2016.

[34] Y. Du, T. Fan, H. G. Machel, and Z. Gao, "Genesis of Upper Cambrian-Lower Ordovician dolomites in the Tahe Oilfield, Tarim Basin, NW China: several limitations from petrology, geochemistry, and fluid inclusions," Marine and Petroleum Geology, vol. 91, pp. 43-70, 2018.

[35] D. Zhu, D. Zhang, Q. Liu et al., "Formation mechanism of dolomite reservoir controlled by fourth-order sequence in an evaporated marine environment - an example from the lower Ordovician Tongzi Formation in the Sichuan Basin," Energy Exploration \& Exploitation, vol. 36, no. 4, pp. 620-644, 2018.

[36] S. Boggs, Petrology of Sedimentary Rocks, Cambridge University Press, 2009.

[37] Z. Duan and R. Sun, "An improved model calculating $\mathrm{CO}_{2}$ solubility in pure water and aqueous $\mathrm{NaCl}$ solutions from 273 to $533 \mathrm{~K}$ and from 0 to 2000 bar," Chemical Geology, vol. 193, no. 3-4, pp. 257-271, 2003.

[38] J. C. Vogel, P. M. Grootes, and W. G. Mook, "Isotopic fractionation between gaseous and dissolved carbon dioxide," Zeitschrift für Physik A Hadrons and nuclei, vol. 230, no. 3, pp. 225-238, 1970.

[39] C. H. Moore, Carbonate Reservoirs: Porosity and Diagenesis in a Sequence Stratigraphic Framework, Elsevier, 2013.

[40] J. R. O'Neil, R. N. Clayton, and T. K. Mayeda, "Oxygen isotope fractionation in divalent metal carbonates," Journal of Chemical Physics, vol. 51, no. 12, pp. 5547-5558, 1969.

[41] B. Wang and I. S. Al-Aasm, "Karst-controlled diagenesis and reservoir development: example from the Ordovician mainreservoir carbonate rocks on the eastern margin of the Ordos basin, China," AAPG Bulletin, vol. 86, no. 9, pp. 1639-1658, 2002.

[42] W. Zhao, A. Shen, Z. Qiao, J. Zheng, and X. Wang, "Carbonate karst reservoirs of the Tarim Basin, Northwest China: types, features, origins, and implications for hydrocarbon exploration,” Interpretation, vol. 2, no. 3, pp. SF65-SF90, 2014.

[43] P. D. Hays and E. L. Grossman, "Oxygen isotopes in meteoric calcite cements as indicators of continental paleoclimate," Geology, vol. 19, no. 5, pp. 441-444, 1991.

[44] C. Cai, R. H. Worden, Q. Wang, T. Xiang, J. Zhu, and X. Chu, "Chemical and isotopic evidence for secondary alteration of natural gases in the Hetianhe Field, Bachu Uplift of the Tarim Basin," Organic Geochemistry, vol. 33, no. 12, pp. 1415-1427, 2002.

[45] B. L. Winter, C. M. Johnson, and D. L. Clark, "Strontium, neodymium, and lead isotope variations of authigenic and silicate sediment components from the Late Cenozoic Arctic Ocean: implications for sediment provenance and the source of trace metals in seawater," Geochimica et Cosmochimica Acta, vol. 61, no. 19, pp. 4181-4200, 1997.

[46] Q. Liu, D. Zhu, Q. Meng et al., “The scientific connotation of oil and gas formations under deep fluids and organicinorganic interaction," Science China Earth Sciences, vol. 62, no. 3, pp. 507-528, 2019.

[47] D. Zhu, Z. Jin, and W. Hu, "Hydrothermal recrystallization of the Lower Ordovician dolomite and its significance to reservoir in northern Tarim Basin," Science China Earth Sciences, vol. 53, no. 3, pp. 368-381, 2010.

[48] H. Chen, S. Yang, C. Dong et al., "Geological thermal events in Tarim Basin," Chinese Science Bulletin, vol. 42, no. 7, pp. 580584, 1997. 
[49] D. Chen, J. Wang, H. Qing, D. Yan, and R. Li, "Hydrothermal venting activities in the Early Cambrian, South China: petrological, geochronological and stable isotopic constraints," Chemical Geology, vol. 258, no. 3-4, pp. 168-181, 2009.

[50] S. Liu, W. Huang, C. Chen et al., "Primary study on hydrothermal fluid activities and its effectiveness on petroleum and mineral accumulation of Sinian system - Paleozoic in Sichuan basin," Journal of Mineralogy and Petrology, vol. 28, no. 3, pp. 41-50, 2008.

[51] R. H. Worden, P. C. Smalley, and N. H. Oxtoby, "Gas souring by thermochemical sulfate reduction at $140^{\circ} \mathrm{C}$," AAPG Bulletin, vol. 79, no. 6, pp. 854-863, 1995.

[52] D. Zhu, Q. Liu, B. Zhou, Z. Jin, and T. Li, "Sulfur isotope of pyrite response to redox chemistry in organic matterenriched shales and implications for components of shale gas," Interpretation, vol. 6, no. 4, pp. SN71-SN83, 2018.

[53] M. B. Goldhaber and W. L. Orr, "Kinetic controls on thermochemical sulfate reduction as a source of sedimentary $\mathrm{H}_{2} \mathrm{~S}$," in Geochemical Transformations of Sedimentary Sulfur, M. A. Vairavamurthy and M. A. Schoonen, Eds., American Chemical Society, 1995.

[54] W. G. Toland, "Oxidation of organic compounds with aqueous sulfate," Journal of the American Chemical Society, vol. 82, no. 8, pp. 1911-1916, 1960.

[55] K. He, S. Zhang, J. Mi, Q. Ma, Y. Tang, and Y. Fang, "Experimental and theoretical studies on kinetics for thermochemical sulfate reduction of oil, $\mathrm{C}_{2-5}$ and methane," Journal of Analytical and Applied Pyrolysis, vol. 139, pp. 59-72, 2019.

[56] W. Zhao, Z. Wang, S. Hu et al., "Large-scale hydrocarbon accumulation factors and characteristics of marine carbonate reservoirs in three large onshore cratonic basins in China," Acta Petrolei Sinica, vol. 33, no. S2, pp. 1-10, 2012.

[57] Q. Meng, D. Zhu, W. Hu, and Z. Jin, "Dissolution-filling mechanism of atmospheric precipitation controlled by both thermodynamics and kinetics," Science China Earth Sciences, vol. 56, no. 12, pp. 2150-2159, 2013.

[58] C. Liu, M. Wu, and G. Gong, "Caledonian karstification of Ordovician carbonates in the Tahe oilfield, northern Tarim basin, Northwest China, and its petroleum geological significance," Geological Bulletin of China, vol. 25, no. 9-10, pp. 1128-1134, 2006.

[59] Z. Duan and D. Li, "Coupled phase and aqueous species equilibrium of the $\mathrm{H}_{2} \mathrm{O}-\mathrm{CO}_{2}-\mathrm{NaCl}-\mathrm{CaCO}_{3}$ system from 0 to 250 ${ }^{\circ} \mathrm{C}, 1$ to 1000 bar with $\mathrm{NaCl}$ concentrations up to saturation of halite," Geochimica et Cosmochimica Acta, vol. 72, no. 20, pp. 5128-5145, 2008.

[60] X. Wei, J. Ren, J. Zhao et al., "Paleo-geomorphologic characteristic evolution and geological significance of the Ordovician weathering crust in eastern Ordos Basin," Acta Petrolei Sinica, vol. 38, no. 9, pp. 999-1009, 2017.

[61] Z. He, Z. Gao, J. Zhang, Q. Ding, and C. Jiao, “Types of sequence boundaries and their control over formation and distribution of quality carbonate reservoirs," Oil and Gas Geology, vol. 35, no. 6, pp. 853-859, 2014.

[62] D. You, J. Han, W. Hu et al., "Characteristics and formation mechanisms of silicified carbonate reservoirs in well SN4 of the Tarim Basin," Energy Exploration \& Exploitation, vol. 36, no. 4 , pp. 820-849, 2017.
[63] D. Zhu, Q. Meng, Z. Jin, and W. Hu, "Fluid environment for preservation of pore spaces in a deep dolomite reservoir," Geofluids, vol. 15, no. 4, 545 pages, 2015.

[64] G. Zhu, S. Zhang, H. Huang, Y. Liang, S. Meng, and Y. Li, "Gas genetic type and origin of hydrogen sulfide in the Zhongba gas field of the western Sichuan Basin, China," Applied Geochemistry, vol. 26, no. 7, pp. 1261-1273, 2011.

[65] L. Jiang, R. H. Worden, and C. F. Cai, "Thermochemical sulfate reduction and fluid evolution of the Lower Triassic Feixianguan Formation sour gas reservoirs, Northeast Sichuan Basin, China," AAPG Bulletin, vol. 98, no. 5, pp. 947-973, 2014.

[66] Y. Ma, X. Guo, T. Guo, R. Huang, X. Cai, and G. Li, “The Puguang gas field: new giant discovery in the mature Sichuan Basin, Southwest China," AAPG Bulletin, vol. 91, no. 5, pp. 627-643, 2007.

[67] X. Tan, L. Zhao, B. Luo et al., "Comparison of basic features and origins of oolitic shoal reservoirs between carbonate platform interior and platform margin locations in the Lower Triassic Feixianguan Formation of the Sichuan Basin, Southwest China," Petroleum Science, vol. 9, no. 4, pp. 417-428, 2012.

[68] S. N. Ehrenberg, O. Walderhaug, and K. Bjørlykke, "Carbonate porosity creation by mesogenetic dissolution: reality or illusion?," AAPG Bulletin, vol. 96, no. 2, pp. 217-233, 2012.

[69] Y. Ma, X. Cai, and G. Li, "Basic characteristics and concentration of the Puguang gas field in the Sichuan Basin," Acta Geologica Sinica, vol. 79, no. 6, pp. 858-865, 2005. 

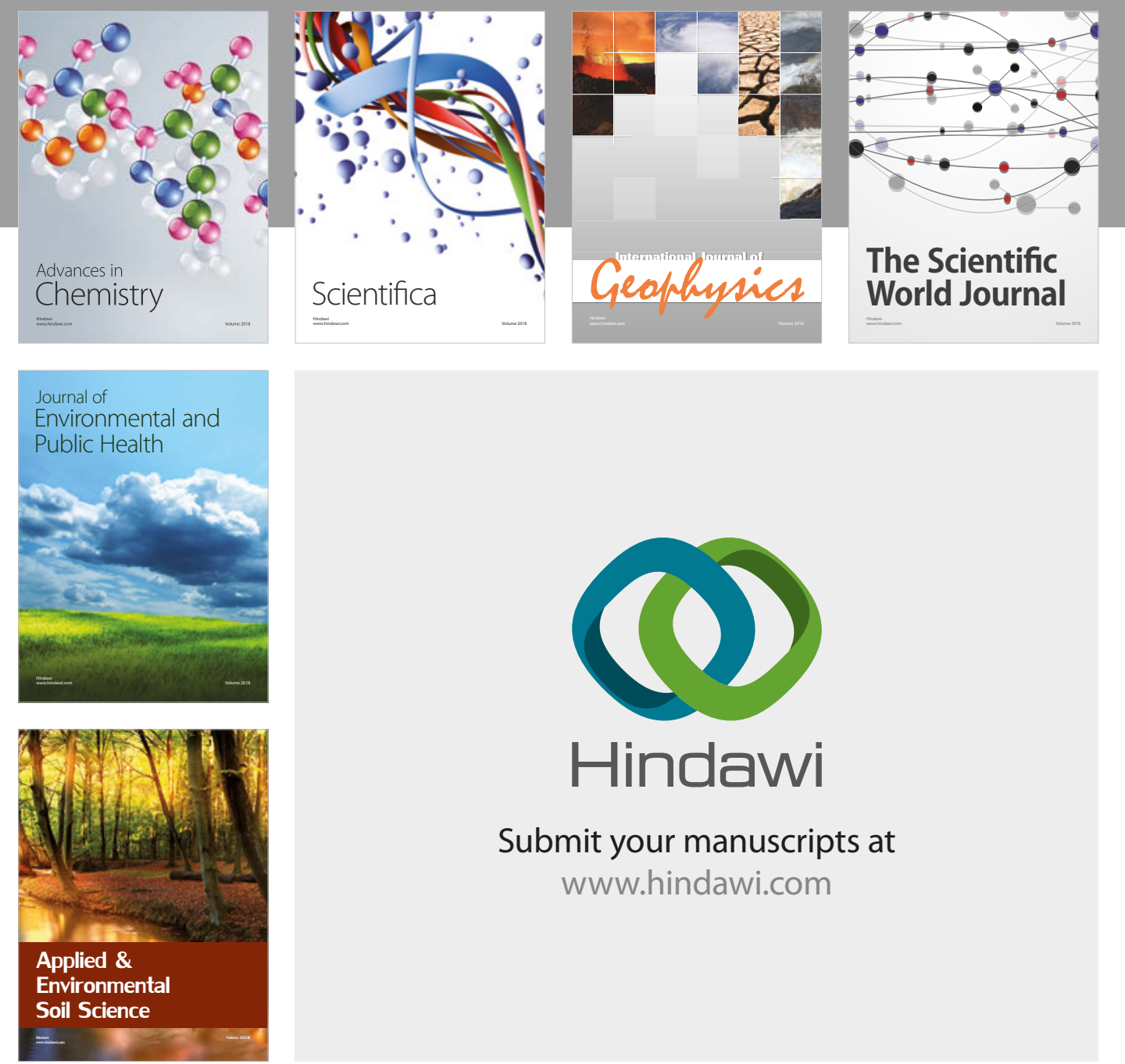

The Scientific

\section{World Journal}
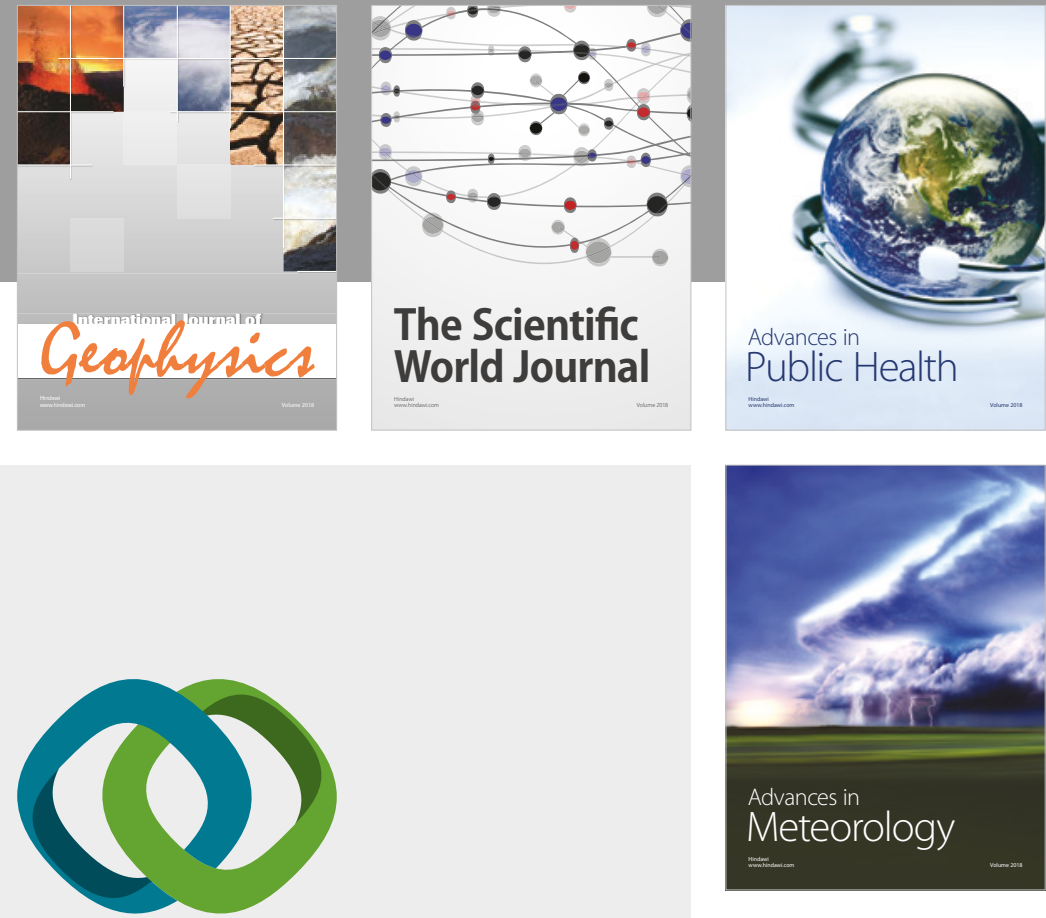

Advan

Public Health

\section{Hindawi}

Submit your manuscripts at

www.hindawi.com
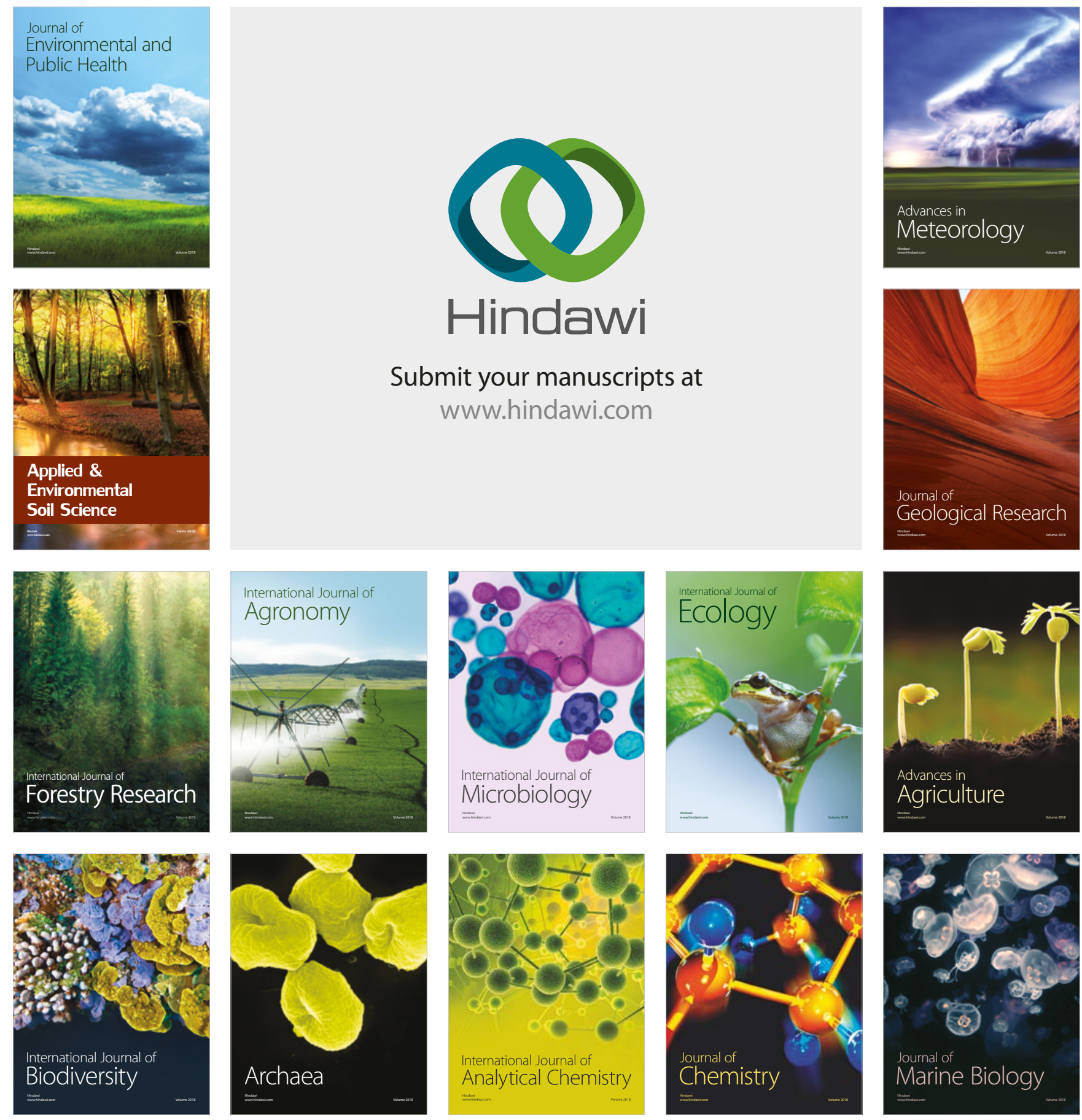